LAWRENCE LIVERMORE N A T IO N A L LABORATORY

LINC Modeling of August 19, 2004 Queen City Barrel Company Fire In Cincinnati, $\mathrm{OH}$

M. B. Dillon, J. S. Nasstrom, R. L. Baskett, B. M. Pobanz

September 15, 2004 


\title{
LINC Modeling of August 19, 2004 Queen City Barrel Company Fire In Cincinnati, OH
}

\author{
Submitted by: \\ Michael B. Dillon, John S. Nasstrom, Ronald L. Baskett, and Brenda M. Pobanz \\ Lawrence Livermore National Laboratory (LLNL) \\ narac@llnl.gov - (925) 422-7627
}

\section{Summary}

This report details the information received, assumptions made, actions taken, and products delivered by the Lawrence Livermore National Laboratory (LLNL) during the August 19, 2004 fire at the Queen City Barrel Company (QCB) in Cincinnati, OH. During the course of the event, LLNL provided four sets of plume model products to various Cincinnati emergency response organizations:

\section{Set 1: Initial (Smoke) Projections,}

Set 2: Initial Fire Plume Health Effect Estimate,

Set 3: Post-Analysis of the Fire Plume, and

Set 4: Initial Smoldering Ember Health Effect Estimate.

Each set of products was developed from information provided by the City of Cincinnati as input to the centralized dispersion modeling system at LLNL's National Atmospheric Release Advisory Center (NARAC). For more details on the modeling system, see: http://narac.llnl.gov.

This work was supported by the Department of Homeland Security (DHS) Local Integration of NARAC with Cities (LINC) program. This program is working with pilot cities to test and demonstrate operational plume modeling tools and services from the NARAC to city agencies.

In using the information provided below, it is important to understand that NARAC plume model predictions are intended to be emergency response guidance, and are not final recommendations. The accuracy of any prediction will be limited by the accuracy of the input data, such as estimates of the material amount and the available meteorological data for the area and time of the incident. Predictions should be confirmed and refined with field measurements before making any final assessment of potential impacts. Concentrations within the inner plume model contour level may be higher than indicated due to the limited resolution of the model and due to finer scale variation in the plume air concentrations that are not simulated by the model. 


\section{Chronology}

\section{Set 1: Initial (Smoke) Projections - Approximately 23:45-23:54 UTC August 19 (19:45-19:54 EDT)}

At about 19:45 EDT on Thursday, August 19, 2004, the Cincinnati Health Department (CHD) alerted the Lawrence Livermore National Laboratory (LLNL) to a fire in progress at the Queen City Barrel Company (QCB) through a call to the NARAC customer support desk. The incident was described as an extremely large fire at a barrel recycling facility with $20+\mathrm{ft}$ flames rising above the building. The facility was described as encompassing a city block with 4 floors above and 2 floors below ground, completely filled with 55 gal drums (stacked 3 high). The location was given as 39.10613N and $84.54837 \mathrm{~W}$. The fire reportedly started $\sim 20$ min prior to the call. CHD was particularly concerned about the health effects associated with the combustion of unknown, organic chemicals potentially contained in the barrels.

LLNL initially provided a set of "smoke" plume map plots to guide the first responders and field monitoring teams to safely approach the scene and identify the downwind areas of concern. Due to the nominal source used, these plots have no estimates of health effects associated with them. As requested by CHD, LLNL posted the Set 1 plots to the NARAC Web site and shared these plume map plots with all Cincinnati related NARAC Web users.

\section{Set 1 Plume Product - Posted 23:54 UTC (19:54 EDT) August 19:}

Hazard Released: A nominal amount, $1 \mathrm{~g}$, of respirable particles (uniform size distribution from 0.01 to $10 \mu \mathrm{m}$, deposition velocity of $0.3 \mathrm{~cm} / \mathrm{s}-$ consistent with fresh combustion particles) were released from a three-dimensional Gaussian spatial distribution (standard deviation of 18.3m) located at the top of the building, $54.9 \mathrm{~m}$ above ground level (LLNL used a conservative assumption that the plume rise was negligible). The particles were released at a constant rate during the entire model run (i.e. LLNL assumed the fire was constantly burning for the entire 6 hours and did not model changes in the fire intensity).

Meteorology Used: LLNL used the National Weather Service ETA (12 km horizontal resolution) weather forecast model output valid at 8/19/04 21:00 UTC, 8/20/04 0:00 UTC, and 8/20/04 3:00 UTC to drive the NARAC dispersion model.

Plots Produced: LLNL produced hourly integrated particulate air concentrations for the first 6 hours of the fire. These products demonstrate only the areas that may be affected by the plume and are not intended to estimate health effects. 


\section{Set 2: Initial Fire Plume Health Effect Estimate - Approximately 1:00-4:19 UTC August 20 (20:00 -23:19 EDT August 19)}

LLNL developed the Set 2 plots to include an estimated airborne release amount based on the choice of a surrogate chemical compound (benzene), field measurements, and a more complete meteorological analysis. The process of developing the Set 2 plots is described below.

1) CHD called the LLNL operations center and started providing air concentration measurements (see Field Measurement Appendix). These measurements were updated periodically over the next several hours.

2) Limited information was available about the burning compounds, thus benzene was chosen as a surrogate compound to estimate the possible plume toxicity (see below). The choice of benzene as a surrogate compound implies dividing the FID measurements by 6 (6 carbon atoms per benzene molecule). Benzene was selected since it is a common industrial chemical and possesses a "middle of the road" acute toxicity in relation to other organic compounds. The accuracy of this assumption and the hazard areas predicted by the plume model strongly depend on how closely the actual hazards in the plume are similar to those posed by benzene. It is important to note that sufficient data did not exist to confirm these assumptions.

Benzene has Emergency Response Planning Guidelines (ERPG) 3, 2, and 1 air concentration levels of 3130,470 , and $156 \mathrm{mg} / \mathrm{m}^{3}$, respectively. The American Industrial Hygiene Association (www.aiha.org) described the ERPG level health implications as:

- The ERPG-3 is the maximum airborne concentration below which it is believed nearly all individuals could be exposed for up to one hour without experiencing or developing lifethreatening health effects.

- The ERPG-2 is the maximum airborne concentration below which it is believed nearly all individuals could be exposed for up to one hour without experiencing or developing irreversible or other serious health effects or symptoms that could impair an individual's ability to take protective action.

- The ERPG-1 is the maximum airborne concentration below which it is believed nearly all individuals could be exposed for up to one hour without experiencing other than mild 
transient adverse health effects or perceiving a clearly

defined objectionable odor.

3) While the plume prediction was being updated to be consistent with available field measurements, CHD called to notify LLNL that the smoke plume was shifting to areas not predicted by the Set 1 plume products. LLNL staff investigated, noted that the local surface weather stations reported light and variable (calm) winds. LLNL informed CHD of the updated weather and noted that the smoke plume, particularly near the fire itself, would likely shift around considerably through the night if the fire remained in its current state and would rise vertically if the fire gained intensity.

4) Before the benzene plume products were shared with Cincinnati emergency response organizations, CHD called with an inventory of the QCB: 20,000 55 gal drums of which a quarter were empty fiber drums, a quarter were empty plastic drums, and half were steel drums. Of the steel drums, 100 contained $\sim 20$ gal of organic chemicals, the remaining contained $\sim 5$ gal of organic chemicals ( 51,500 gal total). CHD relayed the names of several chemicals known to be present in the QCB over the phone to LLNL, the chemicals listed had similar toxicity to benzene.

5) LLNL scaled the amount of benzene released to the atmosphere to be consistent with the FID measurements available and posted these products as Set 2. The amount of organic chemicals released was consistent with the reported QCB inventory. It is important to note that field measurements provide only a limited sample of the variation, in time and space, of the air concentration. As such the airborne release amount is only an approximation for the amount of benzene released, assuming compounds with a toxicity similar to benzene were indeed released.

6) Both emergency responders and the National Weather Service reported scattered thundershowers. LLNL chose not to incorporate rainout effects in the plume model since the spatial and temporal distribution of these showers was not well characterized. Including rainout typically reduces airborne pollutant concentrations and so this assumption is conservative.

7) After posting the Set 2 plots to the NARAC Web, CHD directed LLNL to stand down for the evening.

\section{Set 2 Plume Products -}

Posted 4:19 UTC August 20, 2004 (23:19 EDT August 19):

Hazard Released: 90 tons of benzene (a surrogate compound) was estimated to be released over 12 hrs as respirable particles (uniform size distribution from 0.01 
to $10 \mu \mathrm{m}$, deposition velocity of $0.3 \mathrm{~cm} / \mathrm{s}$ - consistent with fresh combustion particles) from a three-dimensional Gaussian spatial distribution (standard deviation of $18.3 \mathrm{~m}$ ) located above the QCB building (LLNL maintained the conservative assumption that the plume rise was negligible). The hazard was released at a constant rate during the entire model run time (i.e. LLNL assumed the fire was burning for the entire $12 \mathrm{hrs}$ ).

Meteorology Used: LLNL used the National Atmospheric Release Advisory Center (NARAC) system to integrated all available surface and upper air observations ( 100 and 5 stations, respectively) within $25 \mathrm{~km}$ of the fire available that reported observations between 23:00 UTC to 3:00 UTC (Plots valid after 3:00 UTC assume the winds after 3:00 UTC are identical those observed at 3:00 UTC, i.e. persistence).

Plots Produced: Hourly peak 10min benzene air concentrations for the first 12 hours of the fire. These products illustrate the possible health impacts from the fire plume, but should be used with caution since this analysis has the following limitations:

1) assumes that all the toxic material has the same toxicity as benzene (which was unconfirmed),

2) does not account for rainout,

3) does not account for the generic particulate health effects (the NARAC model uses the particulate information only to determine the plume dispersion characteristics and the hazard's ability to enter the lungs),

4) only accounts for acute toxicity and does not address potential chronic effects, and

5) used a limited set of field measurements which do not provide a complete sampling of the plume.

While these plume products are suitable for guidance during an emergency response, LLNL recommends that detailed field measurements be used to determine the potential for health impacts.

\section{Set 3: Post-Analysis of the Fire Plumes - Approximately 14:00-15:33 UTC August 20, 2004 (9:00-10:33 EDT)}

The next morning LLNL produced the Set 3 plume products as updates to the Set 2 benzene hazard plots with new meteorological observations, and information that fire was quenched at 6:00 UTC (1:00 EDT). These plots used a benzene release rate estimated using available field measurements. The amount of organic chemicals released was consistent with the reported QCB inventory. 


\section{Set 3 Plume Product - Posted 15:33 UTC (10:33 EDT) August 20:}

Hazard Released: 52.5ton of benzene (a surrogate compound) was estimated to be released over 7hrs as respirable particles (uniform size distribution from 0.01 to $10 \mu \mathrm{m}$, deposition velocity of $0.3 \mathrm{~cm} / \mathrm{s}$ - consistent with fresh combustion particles) from a three-dimensional Gaussian spatial distribution (standard deviation of $18.3 \mathrm{~m}$ ) located at the top of the building (LLNL maintained the conservative assumption that the plume rise was negligible). The hazard was released at a constant rate during the entire model run time (i.e. LLNL assumed the fire was burning at the same intensity for the entire 7 hours).

Meteorology Used: LLNL used the National Atmospheric Release Advisory Center (NARAC) model to integrated all available surface and upper air observations ( 100 and 5 stations, respectively) within $25 \mathrm{~km}$ of the fire that reported observations between 23:00 UTC to 14:00 UTC.

Plots Produced: Hourly peak 10 min benzene air concentrations for the first 8 hours of the fire. These products illustrate the possible health impacts from the fire plume, but should be used with caution since this analysis has the same set of limitations listed above for Set 2 calculations. While these plume products are suitable for guidance during an emergency response, LLNL recommends that detailed field measurements be used to determine the potential for health impacts.

\section{Set 4: Initial Smoldering Ember Health Effect Estimate - Approximately 17:00-18:36 UTC August 20, 2004 (12:00-15:36 EDT)}

CHD called the NARAC Operations Center and requested a new product to estimate the potential hazards associated with the remaining embers. A light drizzle was reported. LLNL produced the requested plume products and posted them to the NARAC Web.

\section{Set 4 Plume Products - Posted 18:36 UTC (15:36 EDT) August 20:}

Hazard Released: 8.6 tons of benzene (a surrogate compound) was estimated to be released over 8 hrs as respirable particles (size distribution from 0.01 to $10 \mu \mathrm{m}$, deposition velocity of $0.3 \mathrm{~cm} / \mathrm{s}$ - consistent with fresh combustion particles) from a $50 \mathrm{~m}$ radius circle at the surface (LLNL conservatively estimated negligible plume rise). The hazard was released at a constant rate during the entire model run time (i.e. LLNL assumed the embers smoldered for the entire 8 hours). The 
amount released was scaled to be consistent with the single 60 ppm FID measurement made at the corner of Guest and Evans (reported by CHD).

Meteorology Used: LLNL used NARAC system to integrate all available surface and upper air observations ( 100 and 5 stations, respectively) within $25 \mathrm{~km}$ of the fire that reported observations between 23:00 UTC to 17:00 UTC.

Plots Produced: Hourly peak 10 min benzene air concentrations for the first 7 hours of smoldering embers. These products illustrate the possible health impacts from the fire plume, but should be used with caution since this analysis has the same set of limitations listed above for Set 2 calculations. While these plume products are suitable for guidance during an emergency response, LLNL recommends that detailed field measurements be used to determine the potential for health impacts.

\section{Disclaimer}

This work was prepared as an account of work sponsored by an agency of the United States Government. Neither the United States Government nor the University of California nor any of their employees, makes any warranty, express or implied, or assumes any liability or responsibility for the accuracy, completeness, or usefulness of any information, apparatus, products or process disclosed, or represents that its use would not infringe privately-owned rights. Reference herein to any specific commercial products, process or service by trade name, trademark, manufacturer or otherwise does not necessarily constitute or imply its endorsement, recommendation, or favoring by the United States Government or the University of California. The views and opinions of authors expressed herein do not necessarily state or reflect those of the United States Government or the University of California, and shall not be used for advertising or product endorsement purposes.

This work was produced at the University of California, Lawrence Livermore National Laboratory (UC LLNL) under contract W-7405-ENG-48 (Contract 48) between the U.S. Department of Energy (DOE) and The Regents of the University of California (University) for the operation of UC LLNL. Copyright is reserved to the University for purposes of controlled dissemination, commercialization through formal licensing, or other disposition under terms of Contract 48; DOE policies, regulations and orders; and U.S. statutes. The rights of the Federal Government are reserved under Contract 48 subject to the restrictions agreed upon by the DOE and University as allowed under DOE Acquisition Letter 97-1. 


\section{Appendix 1: \\ Field Measurements used to scale the Set 2 and Set 3 source terms}

CHD reported the following field measurements to the LLNL operation center throughout the development of the Set 2 plots:

\begin{tabular}{c|c|c|c|c|c}
$\begin{array}{c}\text { Approximate } \\
\text { Time of } \\
\begin{array}{c}\text { Measurement } \\
\text { (UTC) }\end{array}\end{array}$ & $\begin{array}{c}\text { Location } \\
\text { Description }\end{array}$ & Latitude & Longitude & FID (ppm) & $\begin{array}{c}\text { Other } \\
\mathbf{( p p b )}\end{array}$ \\
\hline \hline 0030 & $\begin{array}{c}\text { Depot and 8 } \\
\text { St. }\end{array}$ & 3906.339 & -8433.094 & 2 to 5 & 300 \\
\hline 0030 & $\begin{array}{c}\text { Edwards and } \\
\text { Observatory }\end{array}$ & 3908.905 & -8426.533 & 4.7 & N/A \\
\hline 0145 & $\begin{array}{c}\text { University } \\
\text { Hospital }\end{array}$ & 39.0809 & -84.3011 & 0 & N/A \\
\hline 0145 & Unknown 1 & 39.11523 & -84.5470 & 1.17 & 159 \\
\hline 0145 & Unknown 2 & 39.087 & -84.54556 & 1.28 & 178 \\
\hline 0145 & Unknown 3 & 39.10765 & -84.54797 & 1.5 & N/A \\
\hline 0145 & Unknown 4 & 39.10771 & -84.54885 & 1.4 & 218 \\
\hline 0145 & $\begin{array}{c}\text { Devon's } \\
\text { Hospital }\end{array}$ & 39.0747 & -84.3123 & 0 & N/A \\
\hline 0100 & Unknown 6 & 39.13903 & -84.47932 & 5.7 & 0.17 \\
\hline After 0100 & Sawyer Pt. & 39.0604 & -84.2959 & 0 & N/A \\
\hline & & & & & \\
\hline
\end{tabular}

† Additional measurements at Unknown 1 include: Hydrogen Sulfide < (unspecified) detection limit, Vinyl Chloride $<0.5 \mathrm{ppm}$, and Benzene $<0.2 \mathrm{ppm}$. The Vinyl Chloride and Benzene concentrations reported were below the levels of concern established by the Department of Energy Temporary Emergency Exposure Limits and American Industrial Hygiene Association Emergency Response Planning Guidelines.

LLNL used only the FID observations to estimate the emission source since, due to severe time constraints, LLNL was unable to obtain a sufficiently detailed description of the "Other" measurement technique. LLNL notes that FID detectors measure the total number of carbon atoms in the air sample. Thus the raw FID measurements were appropriately scaled to develop the benzene source term described above (e.g. [benzene] = FID/6). Benzene was used as a surrogate for chemical compounds potentially released (see discussion in the Second Set of Plume Model Products section above). This assumption was not confirmed by measurements. 
LLNL chose to exclude the Edwards and Observatory observation from this analysis since the other reported values were consistent with the LLNL model typically within a factor of 2 and the Edwards location was significantly to the south of the modeled plume - consistent with eyewitness reports from this location that described the smoke plume to be "in the distance." 


\section{Appendix 2: LLNL Plume Products}

Some figures are labeled "Not For Public Dissemination" because they are a record of the original figures used during this event.

The figures do not have that restriction now.

\section{Set 1: Initial (Smoke) Projections}

These plume model products illustrate downwind areas that may be affected by the Queen City Barrel Company fire plume using a forecast model (12km ETA). These products provide only relative concentrations. NO HEALTH AFFECTS ARE INDICATED IN THESE PLUME PRODUCTS.

\section{Set 2: Initial Fire Plume Health Effect Estimates}

These plume products illustrate the modeled health effects from the Queen City Barrel Company fire plume using local meteorological observations (persistence of the 3:00 UTC observations is assumed for plots valid at 4:00 UTC and after). This analysis incorporates a updated airborne chemical release amount compared to the Set 1 analysis. LLNL assumes that the hazard released is approximately as toxic as benzene. This assumption is unconfirmed by measurements.

\section{Set 3: Post-analysis of the Fire Plume}

These plume products use the same source term developed for Set 2, but the meteorology is based on the actual surface and upper air observations throughout the model run. LLNL assumes that the hazard released is approximately as toxic as benzene. This assumption is unconfirmed by measurements.

\section{Set 4: Initial Smoldering Ember Health Effect Estimates}

These plume products illustrate the modeled health effects from the smoldering ember plume. The compound released was assumed to be benzene and the release rate was scaled to match a single field measurement. LLNL assumes that the hazard released is approximately as toxic as benzene. This assumption is unconfirmed by measurements. 


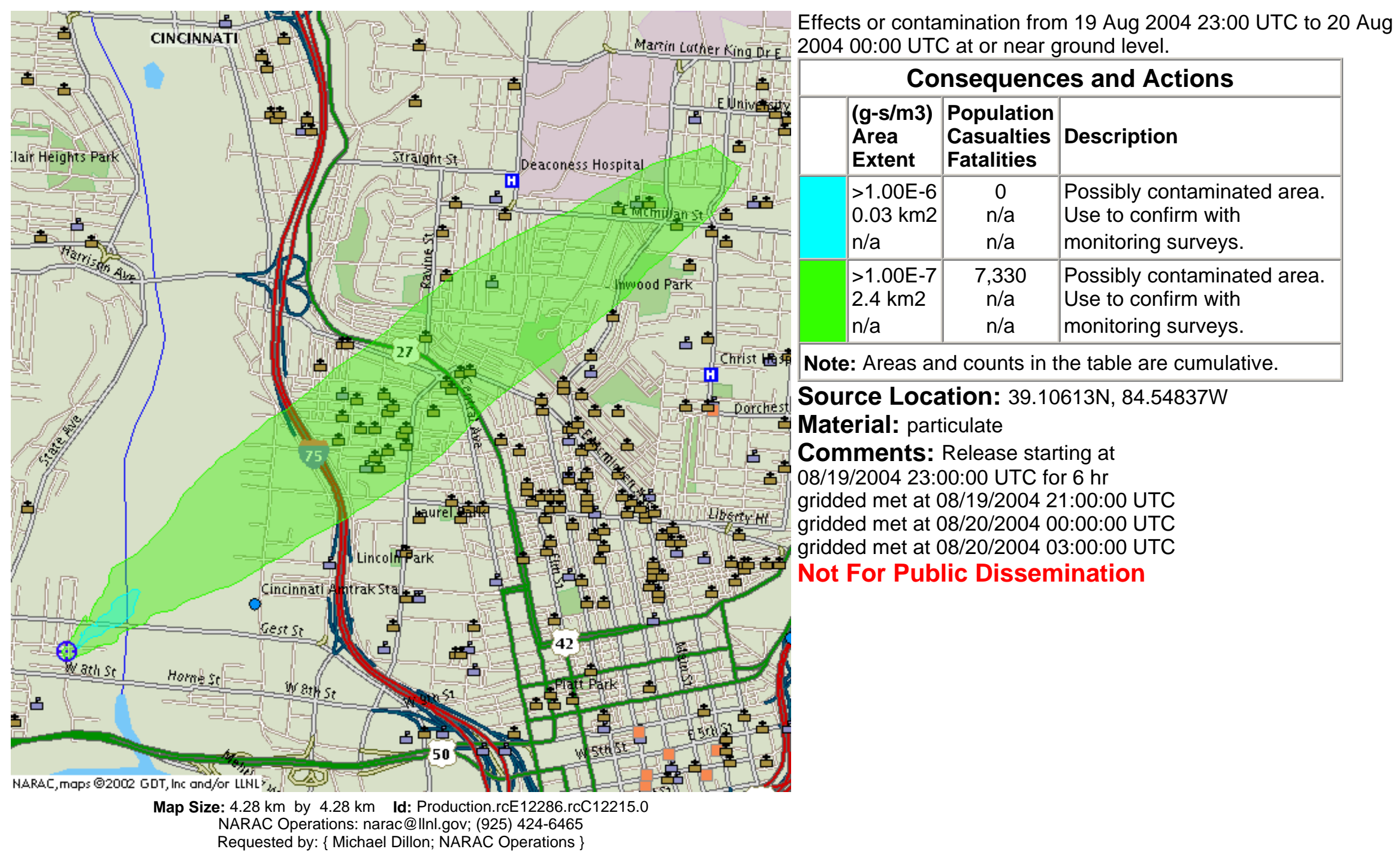




\section{QNoveras}

Integ. Air Conc. of particulate

Set 1: Warehouse Fire - smoke plume Automated Report - Actual Release

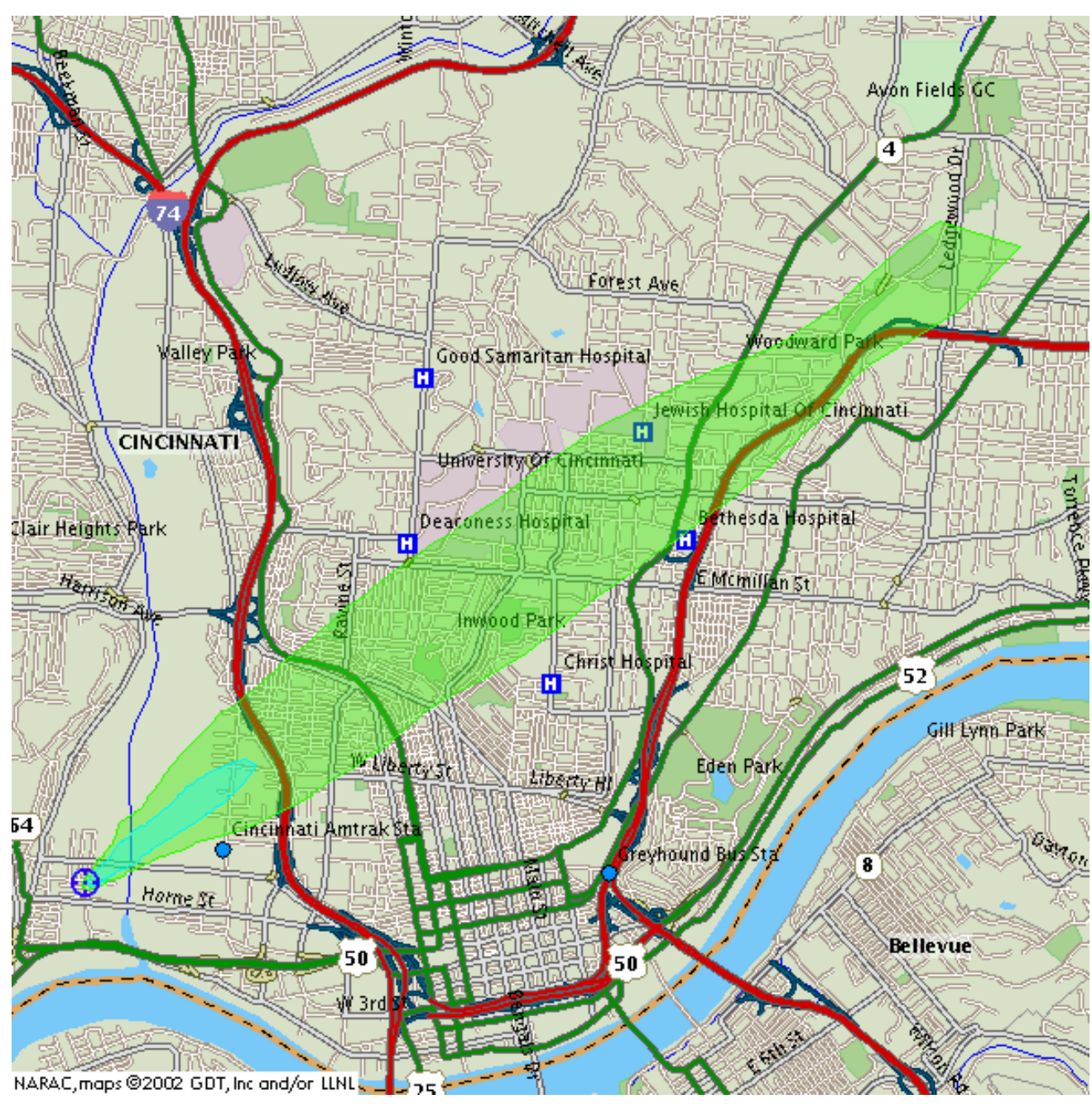

Map Size: $8.19 \mathrm{~km}$ by $8.19 \mathrm{~km}$ Id: Production.rcE12286.rcC12215.0

NARAC Operations: narac@llnl.gov; (925) 424-6465

Requested by: \{ Michael Dillon; NARAC Operations \}

Effects or contamination from 19 Aug 2004 23:00 UTC to 20 Aug 2004 01:00 UTC at or near ground level.

\begin{tabular}{|l|l|l|l|}
\hline \multicolumn{4}{|c|}{ Consequences and Actions } \\
\hline \multicolumn{1}{|c|}{$\begin{array}{l}\text { (g-s/m3) } \\
\text { Area } \\
\text { Extent }\end{array}$} & $\begin{array}{l}\text { Population } \\
\text { Casualties } \\
\text { Fatalities }\end{array}$ & Description \\
\hline$>1.00 \mathrm{E}-6$ & 17 & Possibly contaminated area. \\
$0.3 \mathrm{~km} 2$ & $\mathrm{n} / \mathrm{a}$ & Use to confirm with \\
$\mathrm{n} / \mathrm{a}$ & $\mathrm{n} / \mathrm{a}$ & monitoring surveys. \\
\hline$>1.00 \mathrm{E}-7$ & 19,337 & Possibly contaminated area. \\
$6.5 \mathrm{~km} 2$ & $\mathrm{n} / \mathrm{a}$ & Use to confirm with \\
$\mathrm{n} / \mathrm{a}$ & $\mathrm{n} / \mathrm{a}$ & monitoring surveys. \\
\hline
\end{tabular}

Source Location: $39.10613 \mathrm{~N}, 84.54837 \mathrm{~W}$

Material: particulate

Comments: Release starting at

08/19/2004 23:00:00 UTC for $6 \mathrm{hr}$

gridded met at 08/19/2004 21:00:00 UTC

gridded met at 08/20/2004 00:00:00 UTC

gridded met at 08/20/2004 03:00:00 UTC

Not For Public Dissemination 


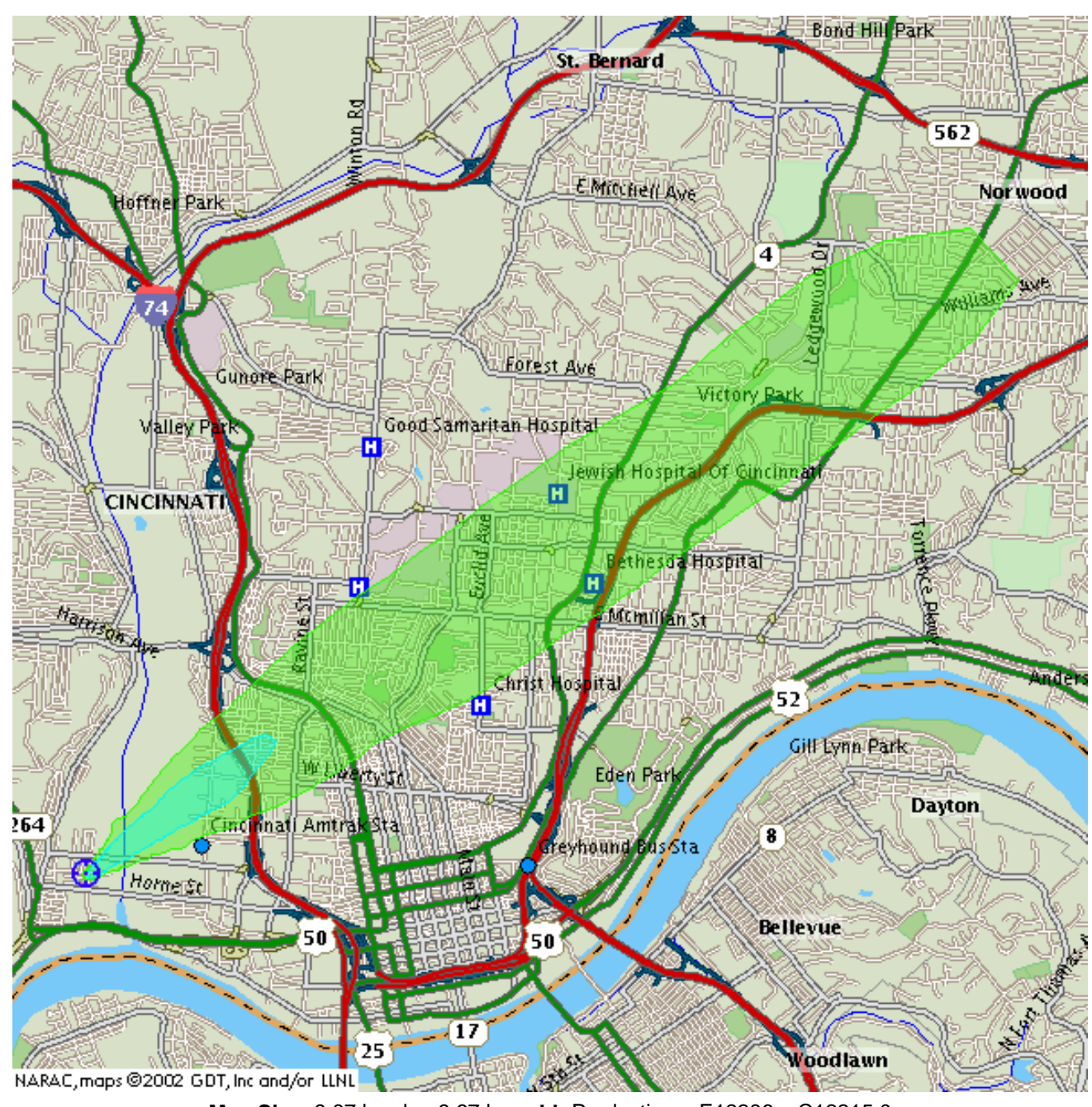

Map Size: $9.67 \mathrm{~km}$ by $9.67 \mathrm{~km}$ Id: Production.rcE12286.rcC12215.0 NARAC Operations: narac@llnl.gov; (925) 424-6465 Requested by: \{ Michael Dillon; NARAC Operations \}
Effects or contamination from 19 Aug 2004 23:00 UTC to 20 Aug 2004 02:00 UTC at or near ground level.

\begin{tabular}{|c|c|c|}
\hline \multicolumn{3}{|c|}{ Consequences and Actions } \\
\hline \begin{tabular}{|l|} 
(g-s/m3) \\
Area \\
Extent
\end{tabular} & $\begin{array}{l}\text { Population } \\
\text { Casualties } \\
\text { Fatalities }\end{array}$ & Description \\
\hline $\begin{array}{l}>1.00 \mathrm{E}-6 \\
0.5 \mathrm{~km} 2 \\
\mathrm{n} / \mathrm{a}\end{array}$ & $\begin{array}{l}519 \\
\mathrm{n} / \mathrm{a} \\
\mathrm{n} / \mathrm{a}\end{array}$ & $\begin{array}{l}\text { Possibly contaminated area. } \\
\text { Use to confirm with } \\
\text { monitoring surveys. }\end{array}$ \\
\hline $\begin{array}{l}>1.00 \mathrm{E}-7 \\
10.9 \mathrm{~km} 2 \\
\mathrm{n} / \mathrm{a}\end{array}$ & $\begin{array}{l}31,946 \\
\mathrm{n} / \mathrm{a} \\
\mathrm{n} / \mathrm{a}\end{array}$ & $\begin{array}{l}\text { Possibly contaminated area. } \\
\text { Use to confirm with } \\
\text { monitoring surveys. }\end{array}$ \\
\hline
\end{tabular}

Source Location: $39.10613 \mathrm{~N}, 84.54837 \mathrm{~W}$

Material: particulate

Comments: Release starting at

08/19/2004 23:00:00 UTC for $6 \mathrm{hr}$

gridded met at 08/19/2004 21:00:00 UTC

gridded met at 08/20/2004 00:00:00 UTC

gridded met at 08/20/2004 03:00:00 UTC

Not For Public Dissemination 


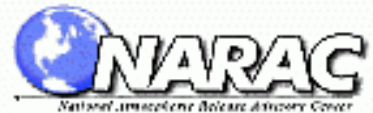

Integ. Air Conc. of particulate

Set 1: Warehouse Fire - smoke plume Automated Report - Actual Release

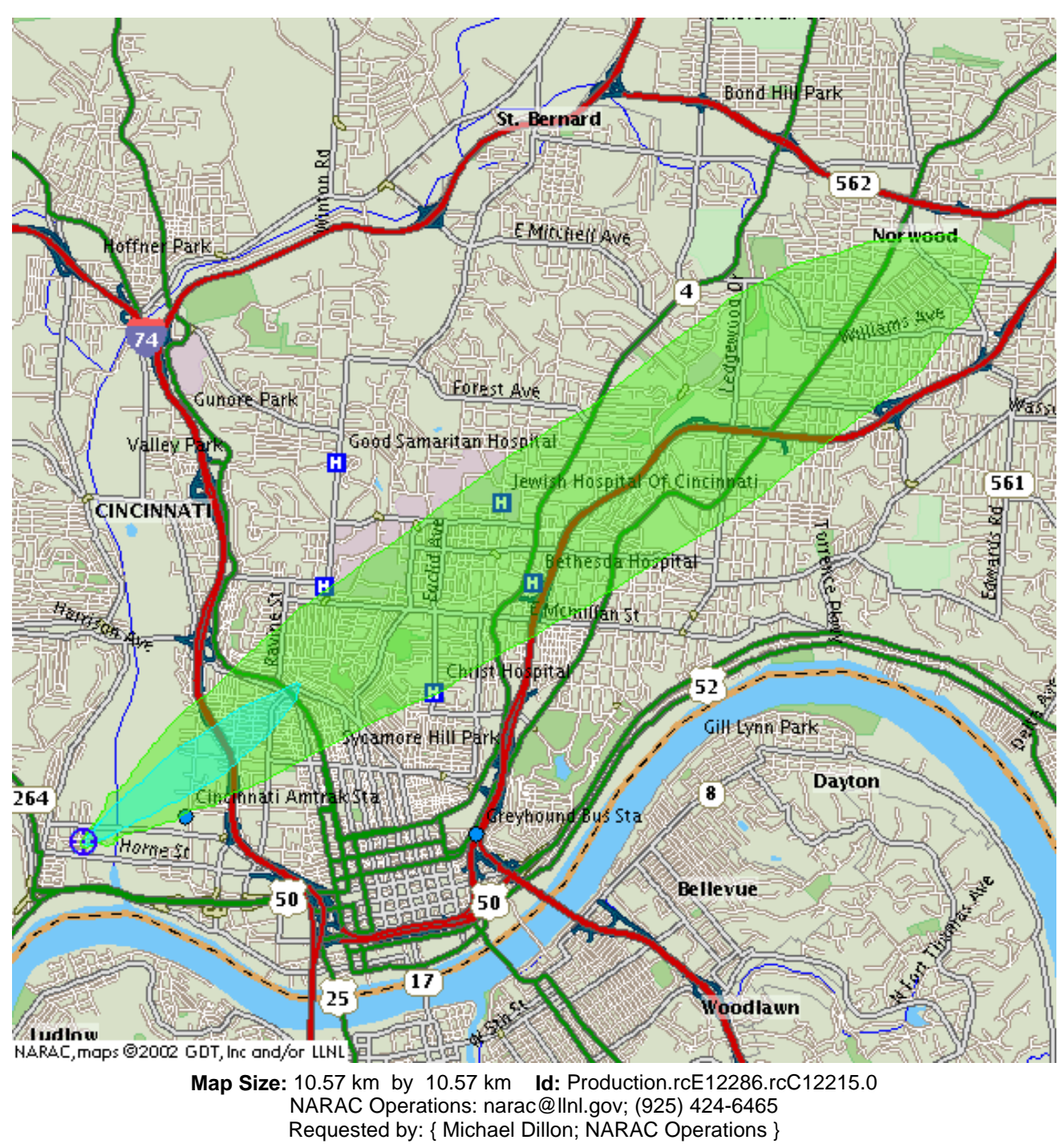

Effects or contamination from 19 Aug 2004 23:00 UTC to 20 Aug 2004 03:00 UTC at or near ground level.

\begin{tabular}{|c|c|c|}
\hline \multicolumn{3}{|c|}{ Consequences and Actions } \\
\hline $\begin{array}{l}(\mathrm{g}-\mathrm{s} / \mathrm{m} 3) \\
\text { Area } \\
\text { Extent }\end{array}$ & $\begin{array}{l}\text { Population } \\
\text { Casualties } \\
\text { Fatalities } \\
\end{array}$ & Description \\
\hline $\begin{array}{l}>1.00 \mathrm{E}-6 \\
0.8 \mathrm{~km} 2 \\
\mathrm{n} / \mathrm{a}\end{array}$ & $\begin{array}{l}1,537 \\
\mathrm{n} / \mathrm{a} \\
\mathrm{n} / \mathrm{a}\end{array}$ & $\begin{array}{l}\text { Possibly contaminated area. } \\
\text { Use to confirm with } \\
\text { monitoring surveys. }\end{array}$ \\
\hline $\begin{array}{l}>1.00 \mathrm{E}-7 \\
14.2 \mathrm{~km} 2 \\
\mathrm{n} / \mathrm{a}\end{array}$ & $\begin{array}{l}41,594 \\
\mathrm{n} / \mathrm{a} \\
\mathrm{n} / \mathrm{a}\end{array}$ & $\begin{array}{l}\text { Possibly contaminated area. } \\
\text { Use to confirm with } \\
\text { monitoring surveys. }\end{array}$ \\
\hline
\end{tabular}

Source Location: $39.10613 \mathrm{~N}, 84.54837 \mathrm{~W}$

Material: particulate

Comments: Release starting at

08/19/2004 23:00:00 UTC for $6 \mathrm{hr}$

gridded met at 08/19/2004 21:00:00 UTC

gridded met at 08/20/2004 00:00:00 UTC

gridded met at 08/20/2004 03:00:00 UTC

Not For Public Dissemination 


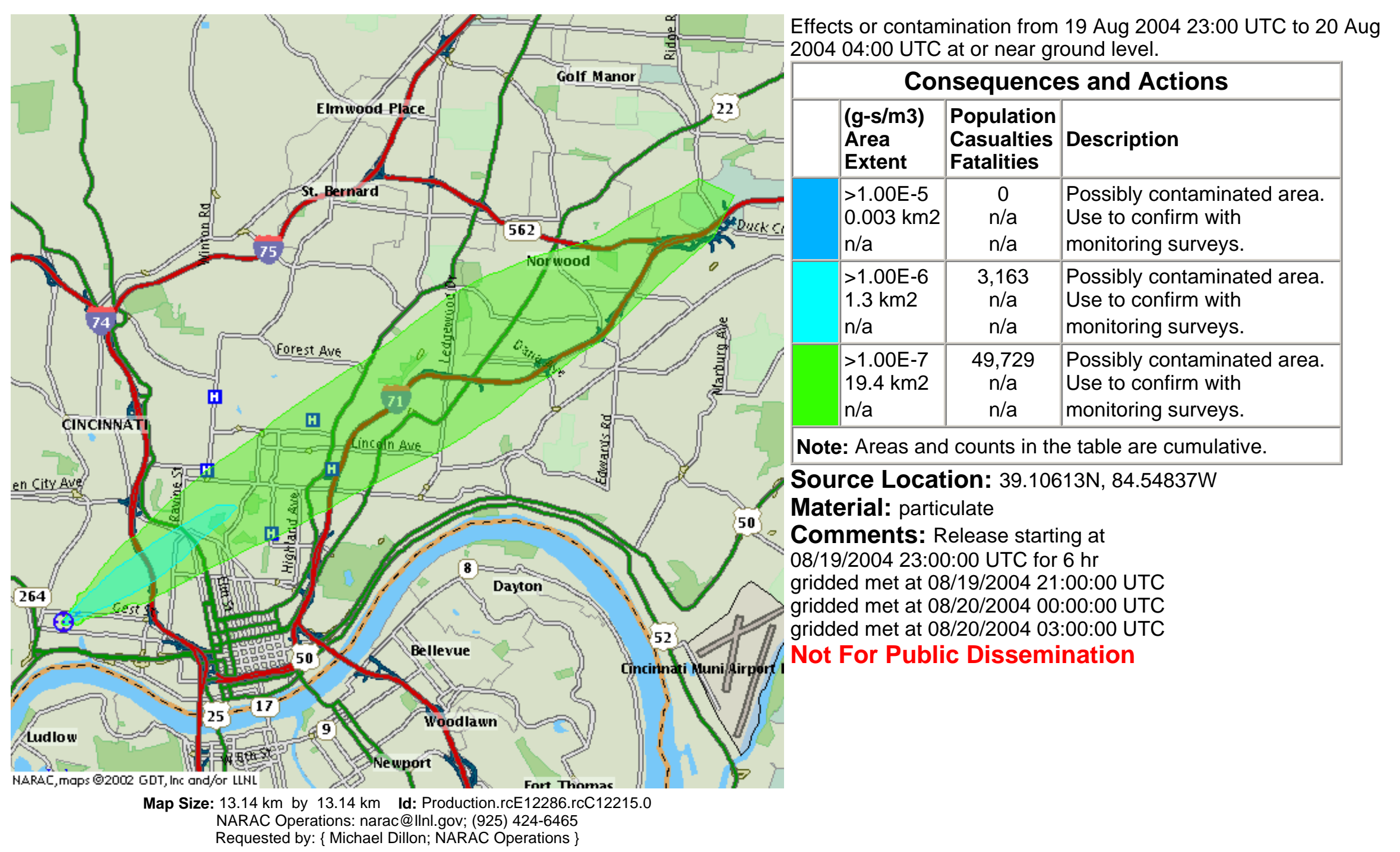




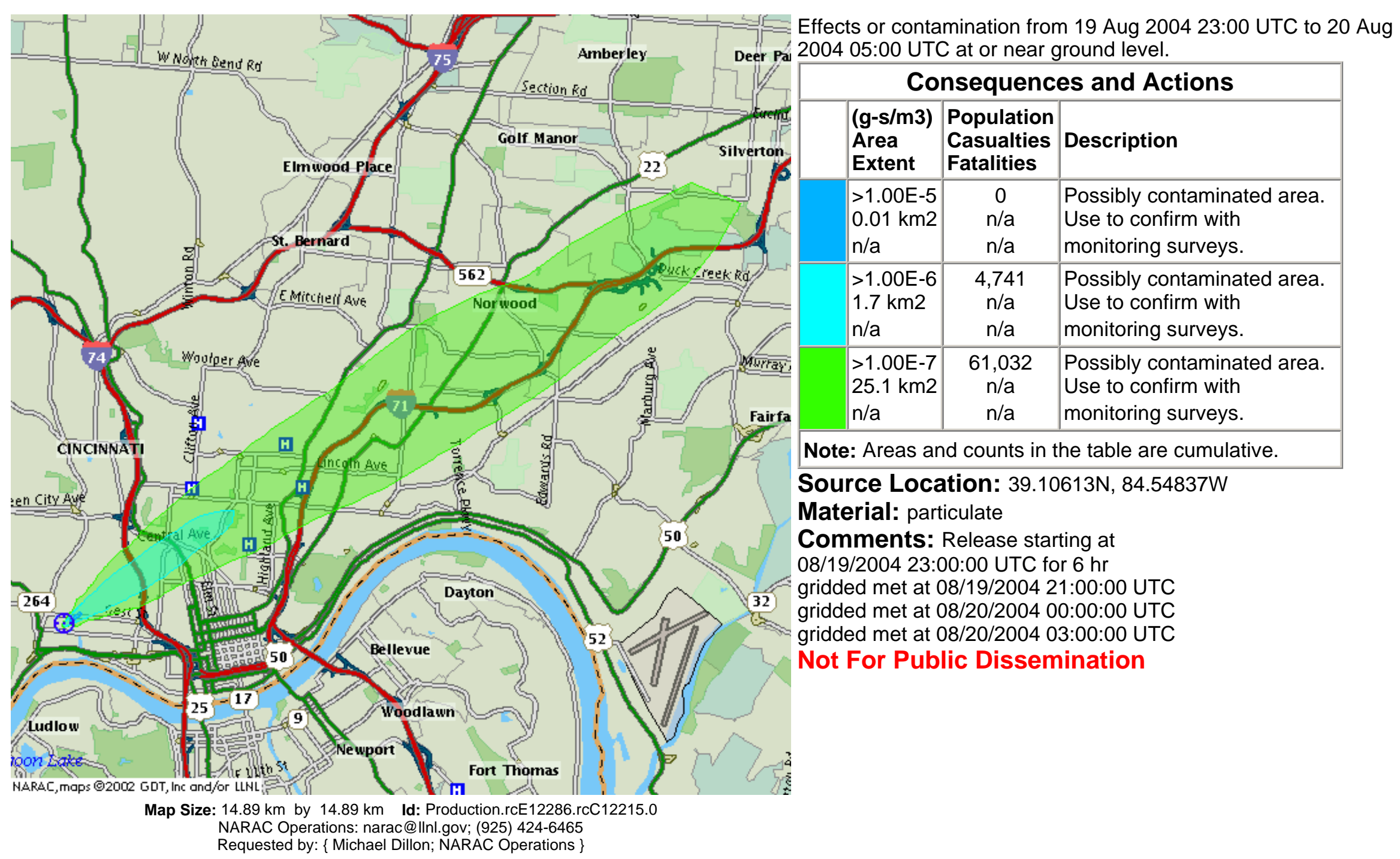




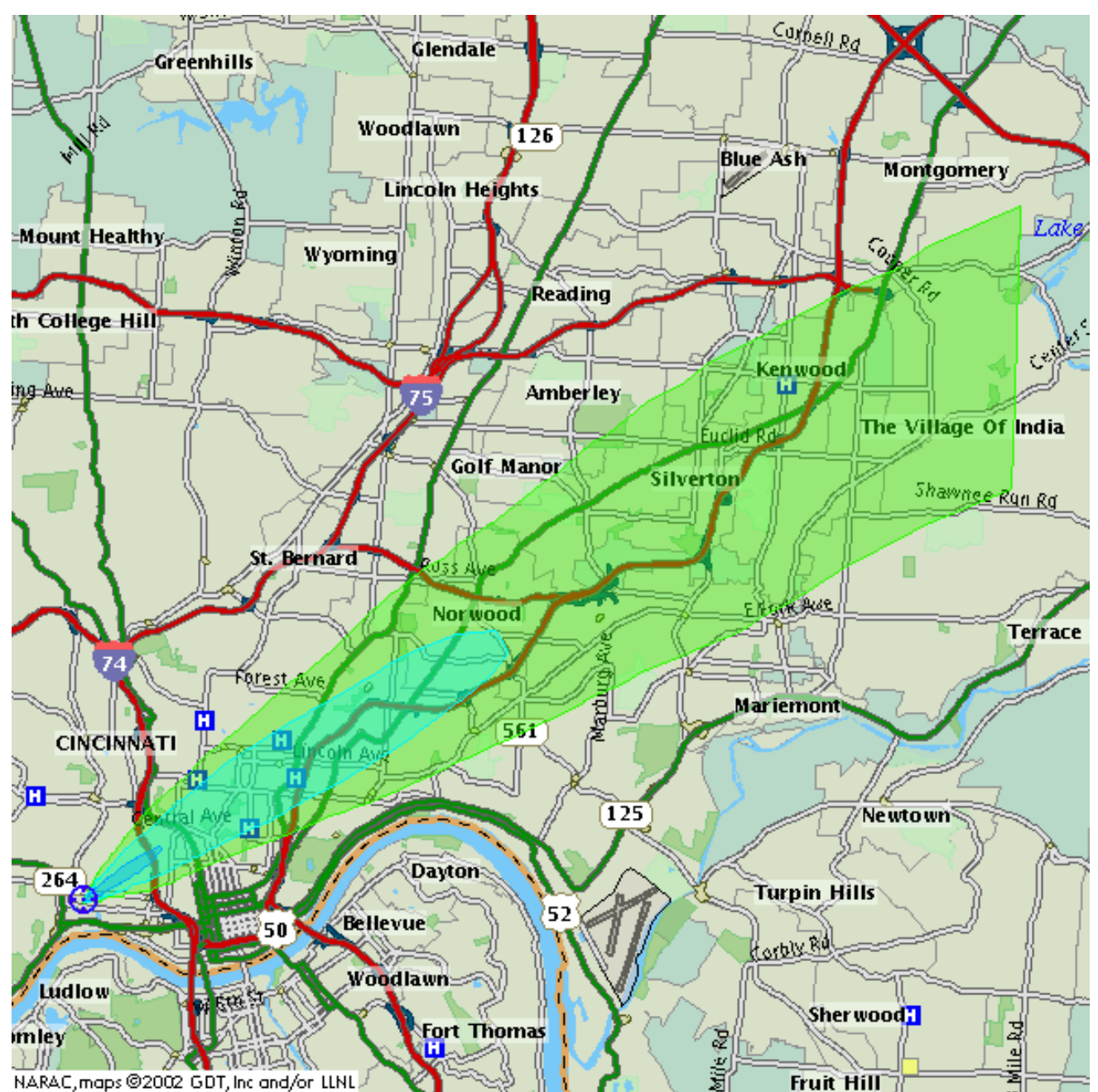

Map Size: $23.08 \mathrm{~km}$ by $23.08 \mathrm{~km}$ Id: Production.rcE12286.rcC12215.0 NARAC Operations: narac@llnl.gov; (925) 424-6465 Requested by: \{ Michael Dillon; NARAC Operations \}
Effects or contamination from 19 Aug 2004 23:00 UTC to 20 Aug 2004 05:00 UTC at or near ground level.

\begin{tabular}{|c|c|c|}
\hline \multicolumn{3}{|c|}{ Consequences and Actions } \\
\hline $\begin{array}{l}(\mathrm{g} / \mathrm{m} 2) \\
\text { Area } \\
\text { Extent }\end{array}$ & $\begin{array}{l}\text { Population } \\
\text { Casualties } \\
\text { Fatalities }\end{array}$ & Description \\
\hline $\begin{array}{l}>1.00 \mathrm{E}-8 \\
0.4 \mathrm{~km} 2 \\
\mathrm{n} / \mathrm{a}\end{array}$ & $\begin{array}{l}343 \\
\mathrm{n} / \mathrm{a} \\
\mathrm{n} / \mathrm{a}\end{array}$ & $\begin{array}{l}\text { Possibly contaminated area. } \\
\text { Use to confirm with } \\
\text { monitoring surveys. }\end{array}$ \\
\hline $\begin{array}{l}>1.00 \mathrm{E}-9 \\
12.8 \mathrm{~km} 2 \\
\mathrm{n} / \mathrm{a}\end{array}$ & $\begin{array}{c}37,813 \\
\mathrm{n} / \mathrm{a} \\
\mathrm{n} / \mathrm{a}\end{array}$ & $\begin{array}{l}\text { Possibly contaminated area. } \\
\text { Use to confirm with } \\
\text { monitoring surveys. }\end{array}$ \\
\hline $\begin{array}{l}>1.00 \mathrm{E}-10 \\
88.3 \mathrm{~km} 2 \\
\mathrm{n} / \mathrm{a}\end{array}$ & $\begin{array}{c}140,605 \\
\text { n/a } \\
n / a\end{array}$ & $\begin{array}{l}\text { Possibly contaminated area. } \\
\text { Use to confirm with } \\
\text { monitoring surveys. }\end{array}$ \\
\hline
\end{tabular}

Source Location: $39.10613 \mathrm{~N}, 84.54837 \mathrm{~W}$

Material: particulate

Comments: Release starting at

08/19/2004 23:00:00 UTC for $6 \mathrm{hr}$

gridded met at 08/19/2004 21:00:00 UTC

gridded met at 08/20/2004 00:00:00 UTC

gridded met at 08/20/2004 03:00:00 UTC

Not For Public Dissemination 


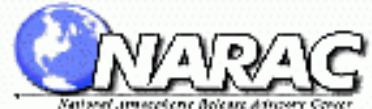

Max 10-min Air Conc over $1 \mathrm{hr}$ at 20 Aug 0000 UTC

Set 2: Hourly 10 min Peak Averages Automated Report - Actual Release

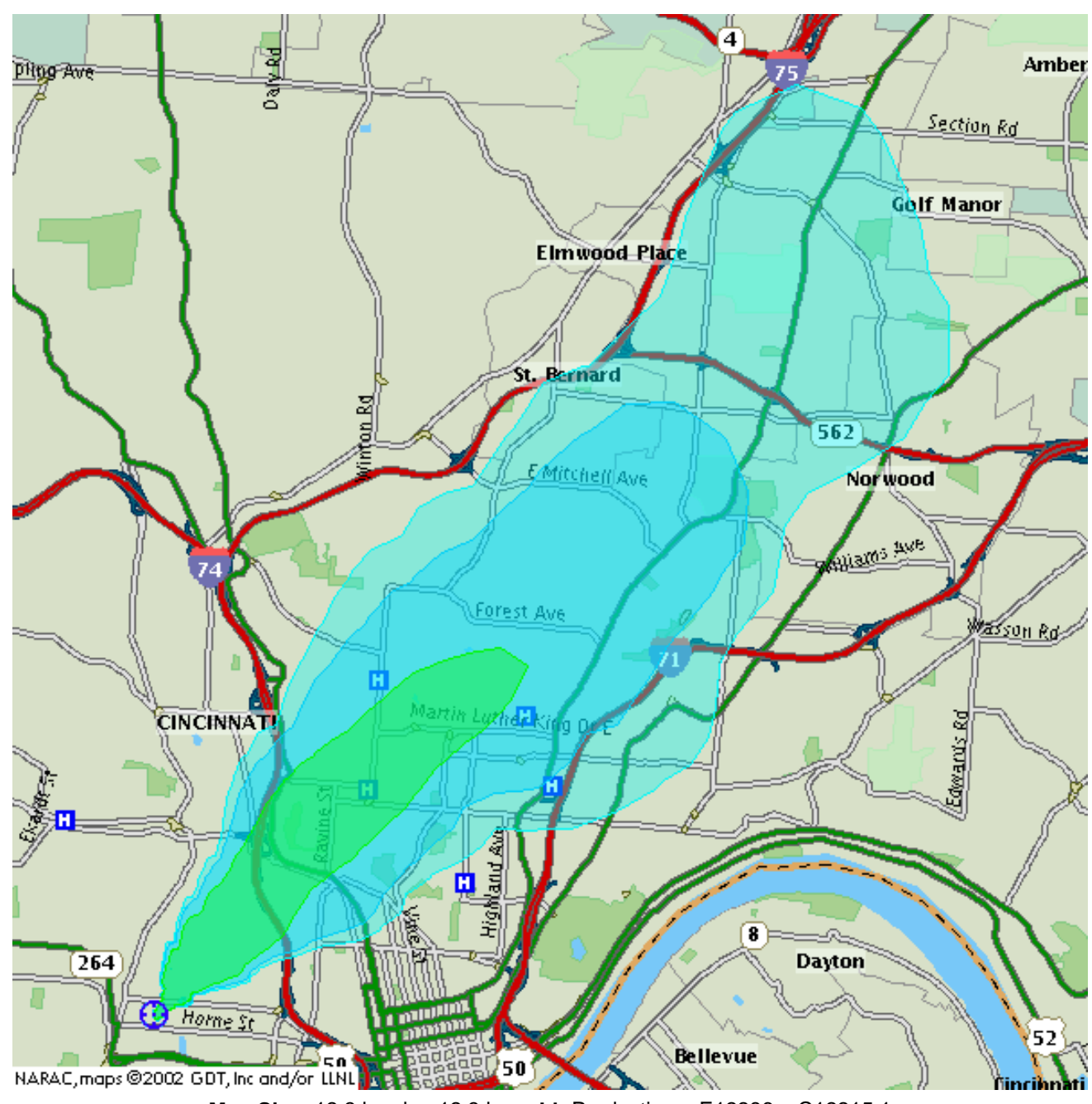

Effects or contamination from 19 Aug 2004 23:00 UTC to 20 Aug er 2004 00:00 UTC at or near ground level.

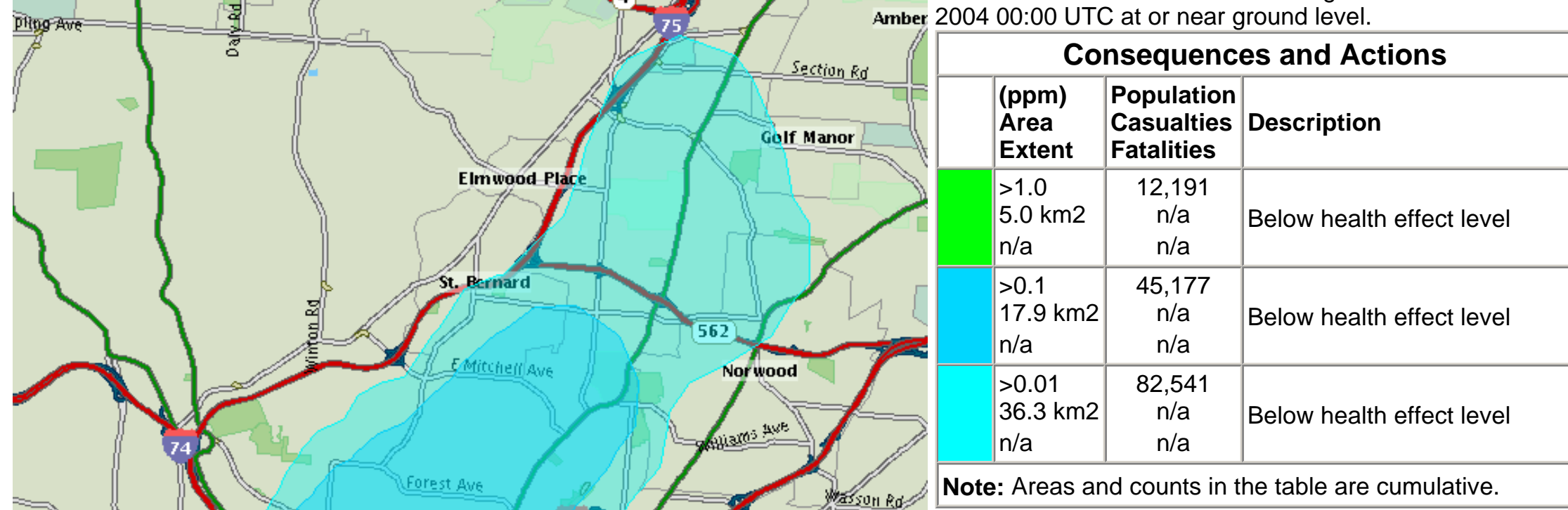

Source Location: $39.10613 \mathrm{~N}, 84.54837 \mathrm{~W}$

Material: BENZENE

Comments: Release starting at

08/19/2004 23:00:00 UTC for $12 \mathrm{hr}$

met obs at 08/19/2004 23:00:00 UTC

met obs at 08/20/2004 00:00:00 UTC

met obs at 08/20/2004 01:00:00 UTC

met obs at 08/20/2004 02:00:00 UTC

Not For Public Dissemination

Map Size: $12.3 \mathrm{~km}$ by $12.3 \mathrm{~km}$ Id: Production.rcE12286.rCC12215.1

NARAC Operations: narac@llnl.gov; (925) 424-6465 


\section{QNoveras}

Max 10-min Air Conc over $1 \mathrm{hr}$ at 20 Aug 0100 UTC

Set 2: Hourly 10 min Peak Averages Automated Report - Actual Release

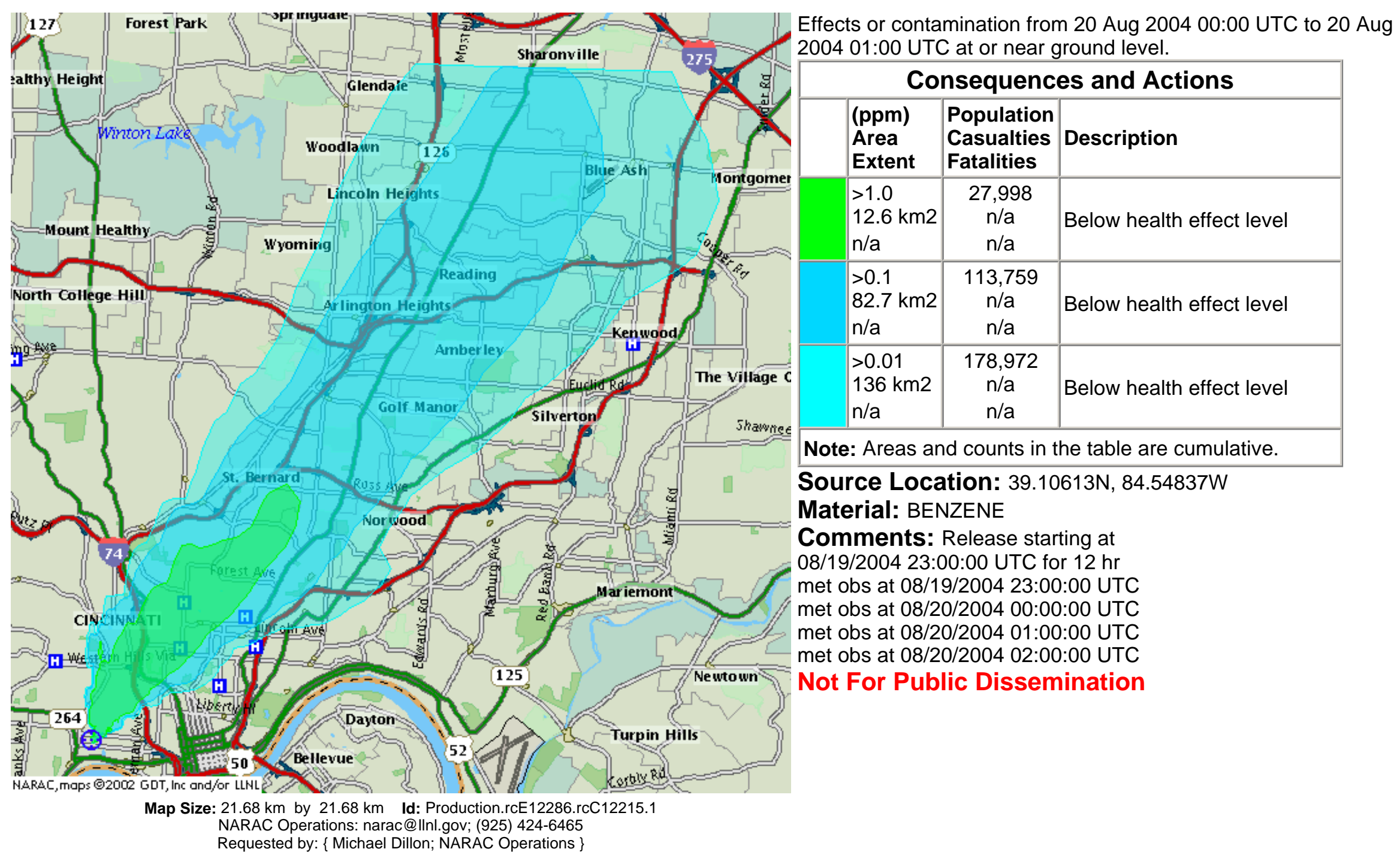




\section{QNoveras}

Max 10-min Air Conc over $1 \mathrm{hr}$ at 20Aug 0200 UTC

Set 2: Hourly 10 min Peak Averages Automated Report - Actual Release

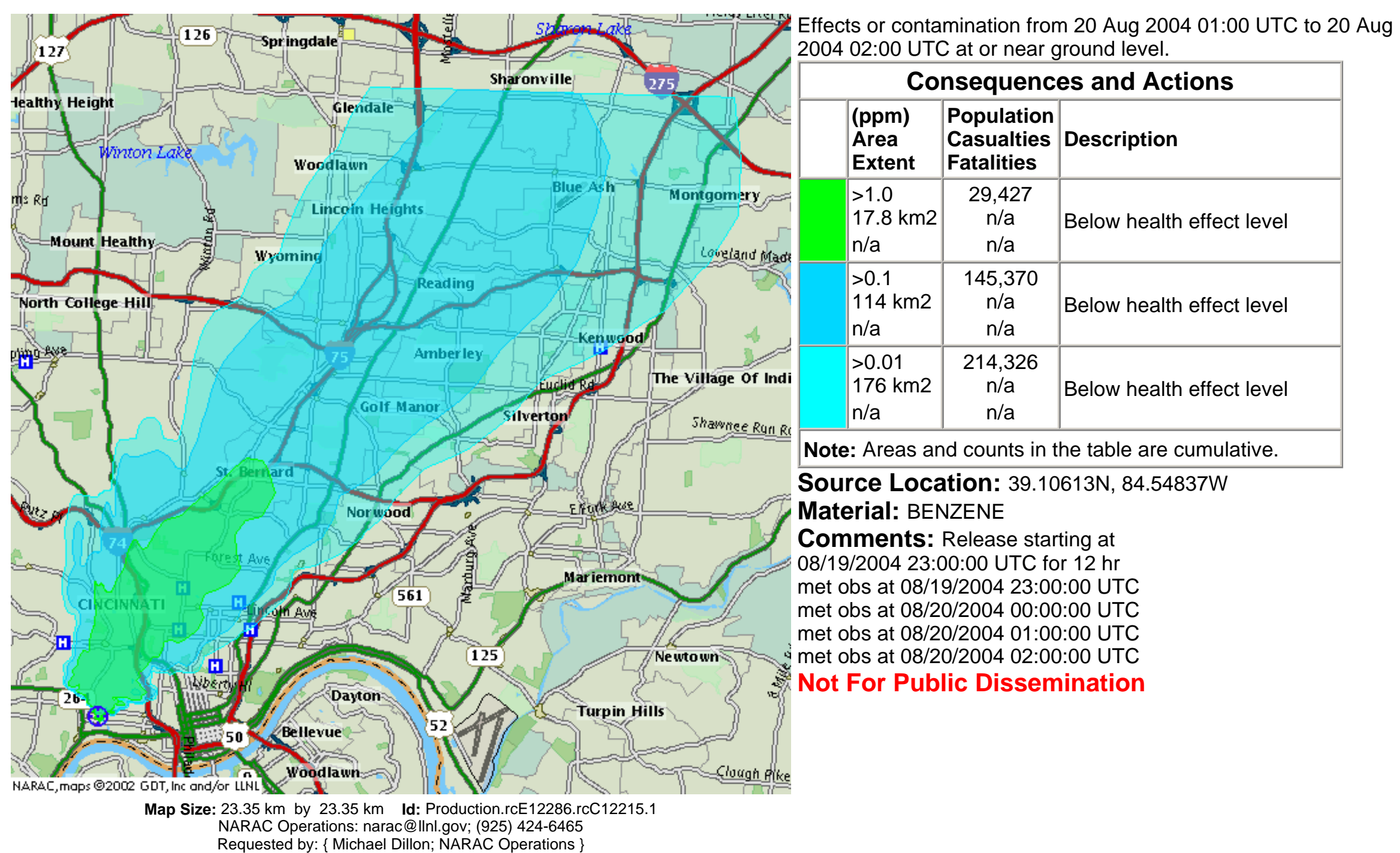




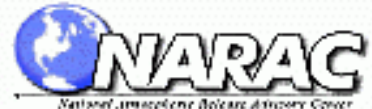

Max 10-min Air Conc over $1 \mathrm{hr}$ at 20 Aug 0300 UTC

Set 2: Hourly 10 min Peak Averages Automated Report - Actual Release

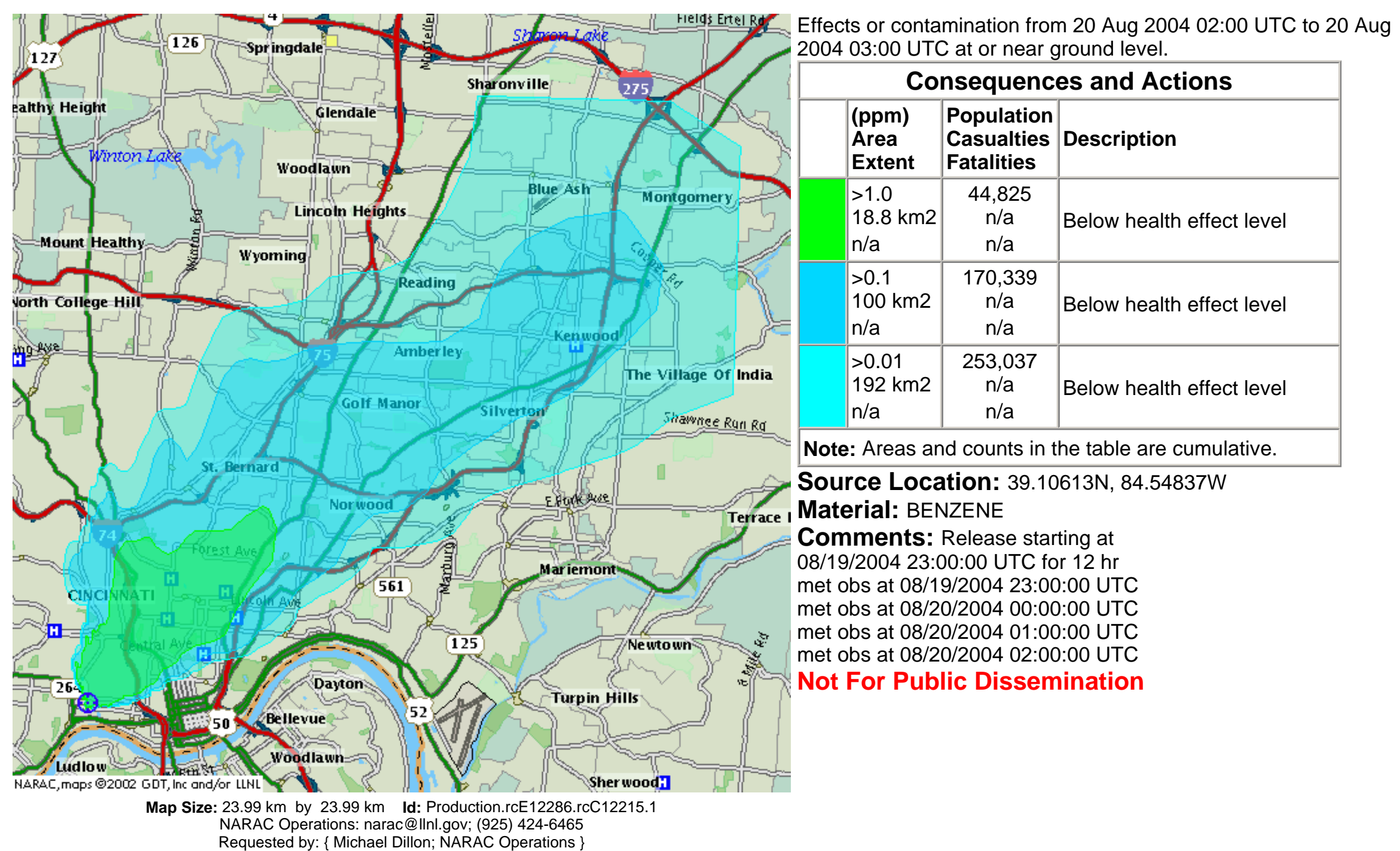




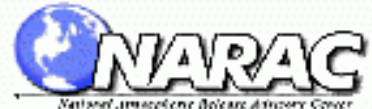

Max 10-min Air Conc over $1 \mathrm{hr}$ at 20 Aug 0400 UTC

Set 2: Hourly 10 min Peak Averages Automated Report - Actual Release

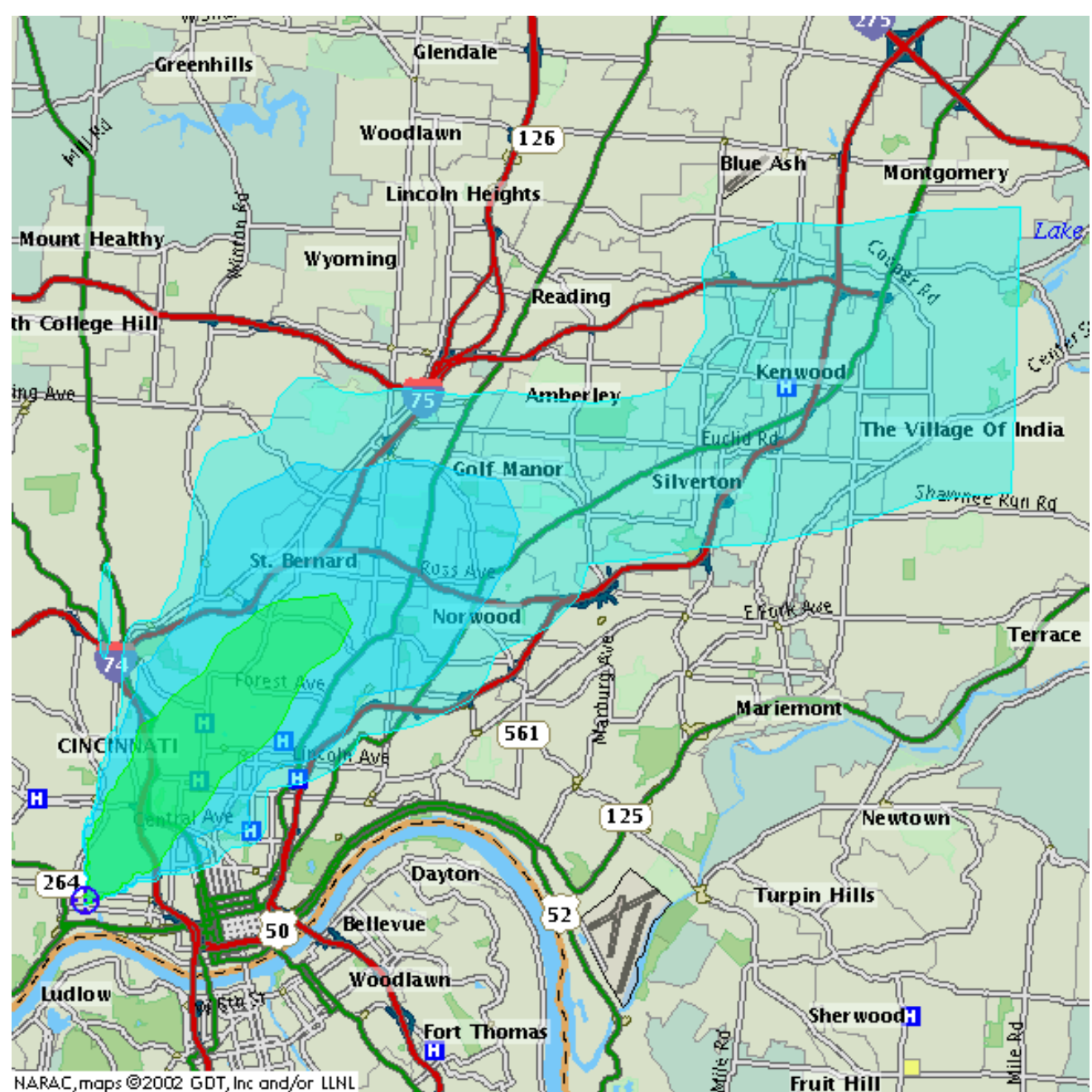

Map Size: $23.12 \mathrm{~km}$ by $23.12 \mathrm{~km}$ Id: Production.rcE12286.rcC12215.1 NARAC Operations: narac@ilni.gov; (925) 424-6465 Requested by: $\{$ Michael Dillon; NARAC Operations \}
Effects or contamination from 20 Aug 2004 03:00 UTC to 20 Aug 2004 04:00 UTC at or near ground level.

\begin{tabular}{|l|l|c|l|}
\hline \multicolumn{4}{|c|}{ Consequences and Actions } \\
\hline \multicolumn{1}{|c|}{$\begin{array}{l}\text { (ppm) } \\
\text { Area } \\
\text { Extent }\end{array}$} & $\begin{array}{l}\text { Population } \\
\text { Casualties } \\
\text { Fatalities }\end{array}$ & Description \\
\hline$>1.0$ & 29,721 & \\
$13.4 \mathrm{~km} 2$ & $\mathrm{n} / \mathrm{a}$ & Below health effect level \\
$\mathrm{n} / \mathrm{a}$ & $\mathrm{n} / \mathrm{a}$ & \\
\hline$>0.1$ & 87,371 & \\
$43.3 \mathrm{~km} 2$ & $\mathrm{n} / \mathrm{a}$ & Below health effect level \\
$\mathrm{n} / \mathrm{a}$ & $\mathrm{n} / \mathrm{a}$ & \\
\hline$>0.01$ & 174,399 & \\
\hline $120 \mathrm{~km} 2$ & $\mathrm{n} / \mathrm{a}$ & Below health effect level \\
n/a & $\mathrm{n} / \mathrm{a}$ & \\
\hline
\end{tabular}

Source Location: 39.10613N, 84.54837W

Material: BENZENE

Comments: Release starting at

08/19/2004 23:00:00 UTC for $12 \mathrm{hr}$

met obs at 08/19/2004 23:00:00 UTC

met obs at 08/20/2004 00:00:00 UTC

met obs at 08/20/2004 01:00:00 UTC

met obs at 08/20/2004 02:00:00 UTC

Not For Public Dissemination 


\section{QNoveras}

Max 10-min Air Conc over $1 \mathrm{hr}$ at 20 Aug 0500 UTC

Set 2: Hourly 10 min Peak Averages Automated Report - Actual Release

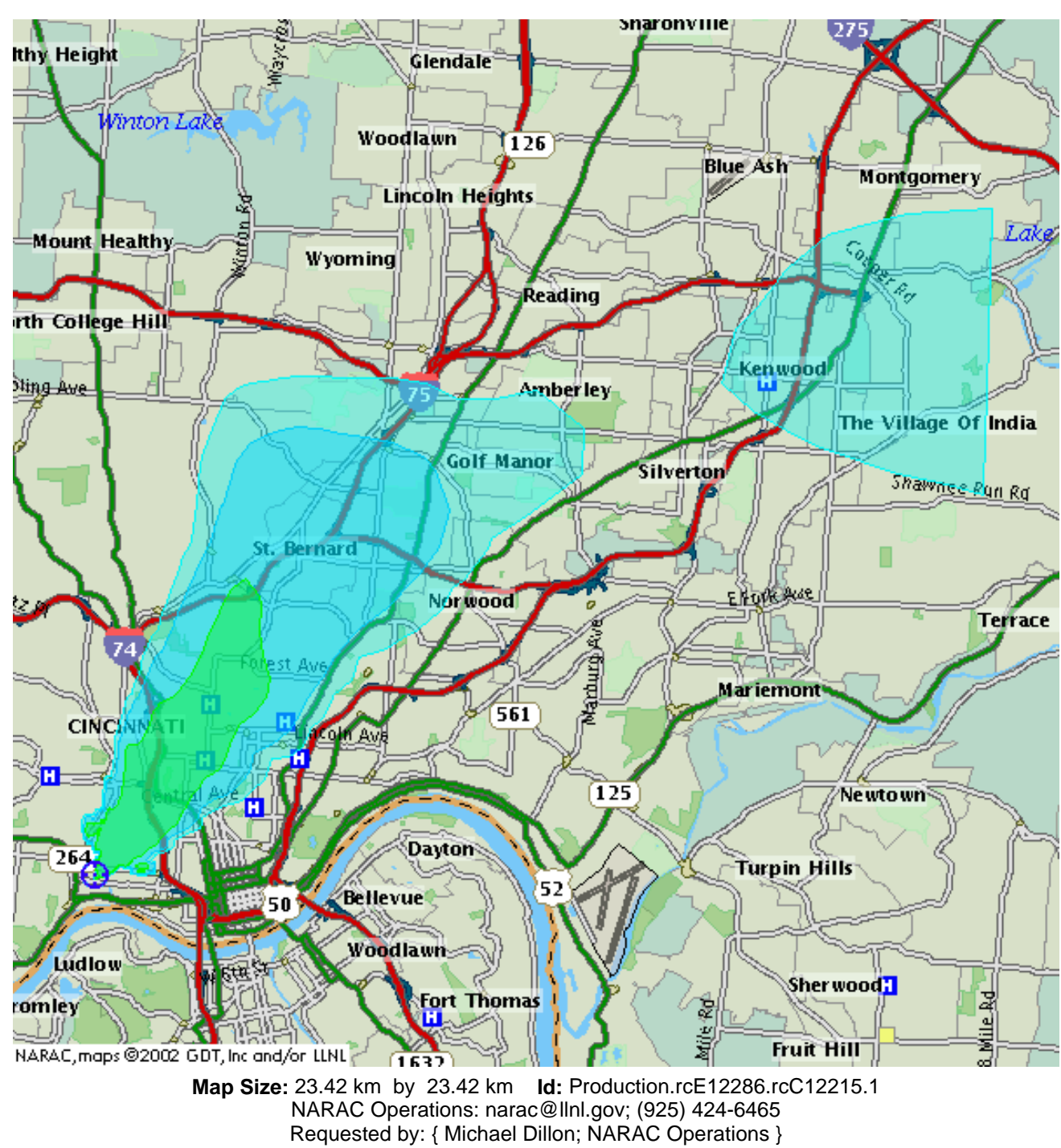

September 14, 2004
Effects or contamination from 20 Aug 2004 04:00 UTC to 20 Aug 2004 05:00 UTC at or near ground level.

\begin{tabular}{|l|l|c|l|}
\hline \multicolumn{3}{|c|}{ Consequences and Actions } \\
\hline \multicolumn{1}{|c|}{$\begin{array}{l}\text { (ppm) } \\
\text { Area } \\
\text { Extent }\end{array}$} & $\begin{array}{l}\text { Population } \\
\text { Casualties } \\
\text { Fatalities }\end{array}$ & Description \\
\hline$>1.0$ & 19,389 & \\
$9.8 \mathrm{~km} 2$ & $\mathrm{n} / \mathrm{a}$ & Below health effect level \\
$\mathrm{n} / \mathrm{a}$ & $\mathrm{n} / \mathrm{a}$ & \\
\hline$>0.1$ & 58,006 & \\
$36.1 \mathrm{~km} 2$ & $\mathrm{n} / \mathrm{a}$ & Below health effect level \\
$\mathrm{n} / \mathrm{a}$ & $\mathrm{n} / \mathrm{a}$ & \\
\hline$>0.01$ & 111,358 & \\
\hline $85.1 \mathrm{~km} 2$ & $\mathrm{n} / \mathrm{a}$ & Below health effect level \\
n/a & $\mathrm{n} / \mathrm{a}$ & \\
\hline
\end{tabular}

Source Location: $39.10613 \mathrm{~N}, 84.54837 \mathrm{~W}$

Material: BENZENE

Comments: Release starting at

08/19/2004 23:00:00 UTC for $12 \mathrm{hr}$

met obs at 08/19/2004 23:00:00 UTC

met obs at 08/20/2004 00:00:00 UTC

met obs at 08/20/2004 01:00:00 UTC

met obs at 08/20/2004 02:00:00 UTC

Not For Public Dissemination 


\section{QNoveras}

Max 10-min Air Conc over $1 \mathrm{hr}$ at 20 Aug 0600 UTC

Set 2: Hourly 10 min Peak Averages Automated Report - Actual Release

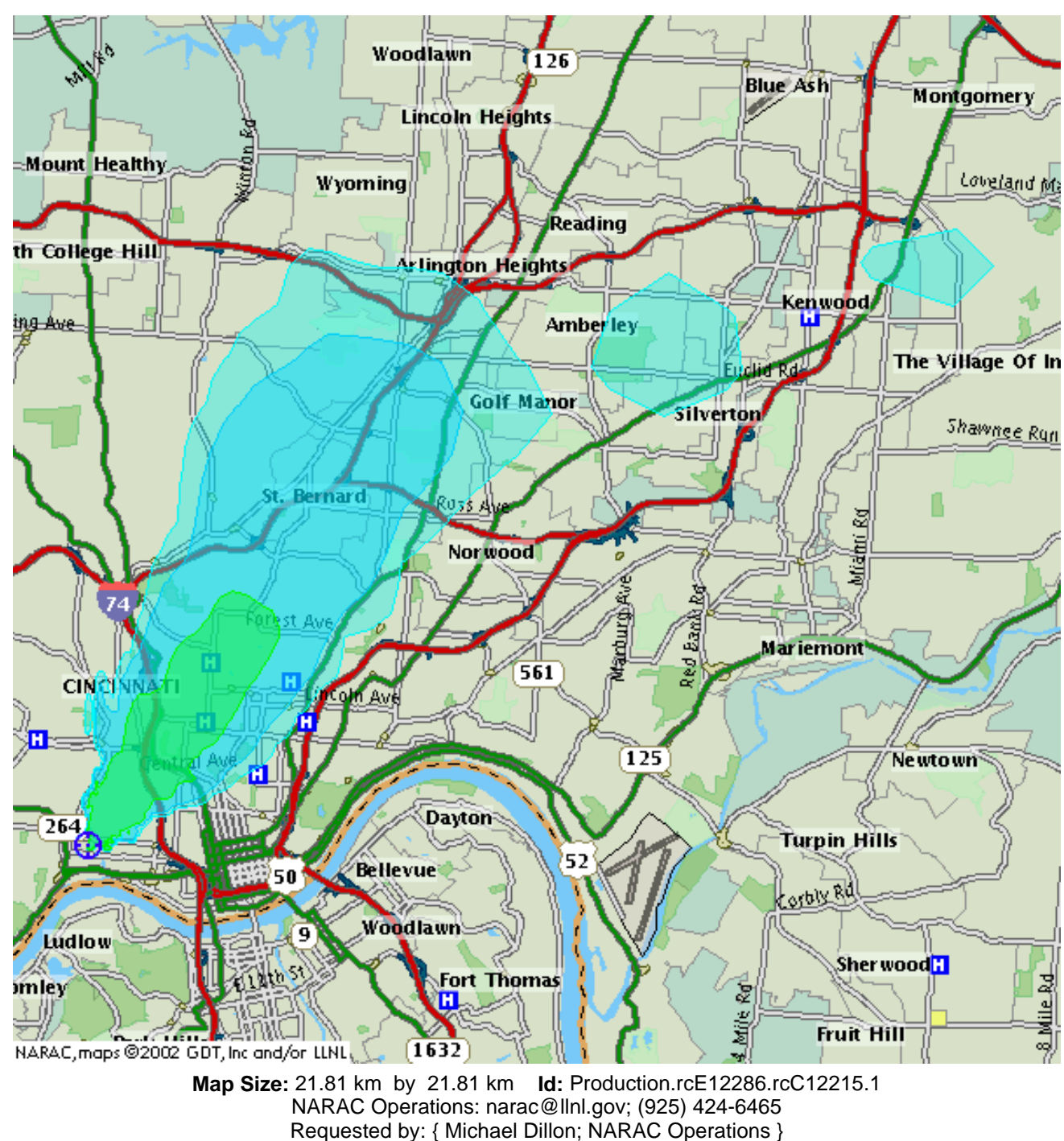

Effects or contamination from 20 Aug 2004 05:00 UTC to 20 Aug 2004 06:00 UTC at or near ground level.

\begin{tabular}{|l|c|c|}
\hline \multicolumn{4}{|c|}{ Consequences and Actions } \\
\hline \begin{tabular}{|l|c|}
\hline (ppm) \\
Area \\
Extent
\end{tabular} & $\begin{array}{l}\text { Population } \\
\text { Casualties } \\
\text { Fatalities }\end{array}$ & Description \\
\hline$>1.0$ & 18,561 & \\
$8.3 \mathrm{~km} 2$ & $\mathrm{n} / \mathrm{a}$ & Below health effect level \\
$\mathrm{n} / \mathrm{a}$ & $\mathrm{n} / \mathrm{a}$ & \\
\hline$>0.1$ & 62,156 & \\
$37.7 \mathrm{~km} 2$ & $\mathrm{n} / \mathrm{a}$ & Below health effect level \\
$\mathrm{n} / \mathrm{a}$ & $\mathrm{n} / \mathrm{a}$ & \\
\hline$>0.01$ & 102,881 & \\
$66.2 \mathrm{~km} 2$ & $\mathrm{n} / \mathrm{a}$ & Below health effect level \\
$\mathrm{n} / \mathrm{a}$ & $\mathrm{n} / \mathrm{a}$ & \\
\hline
\end{tabular}

Source Location: $39.10613 \mathrm{~N}, 84.54837 \mathrm{~W}$

Material: BENZENE

Comments: Release starting at

08/19/2004 23:00:00 UTC for $12 \mathrm{hr}$

met obs at 08/19/2004 23:00:00 UTC

met obs at 08/20/2004 00:00:00 UTC

met obs at 08/20/2004 01:00:00 UTC

met obs at 08/20/2004 02:00:00 UTC

Not For Public Dissemination 


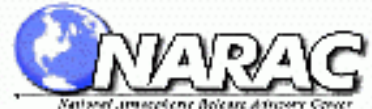

Max 10-min Air Conc over $1 \mathrm{hr}$ at 20Aug 0700 UTC

Set 2: Hourly 10 min Peak Averages Automated Report - Actual Release

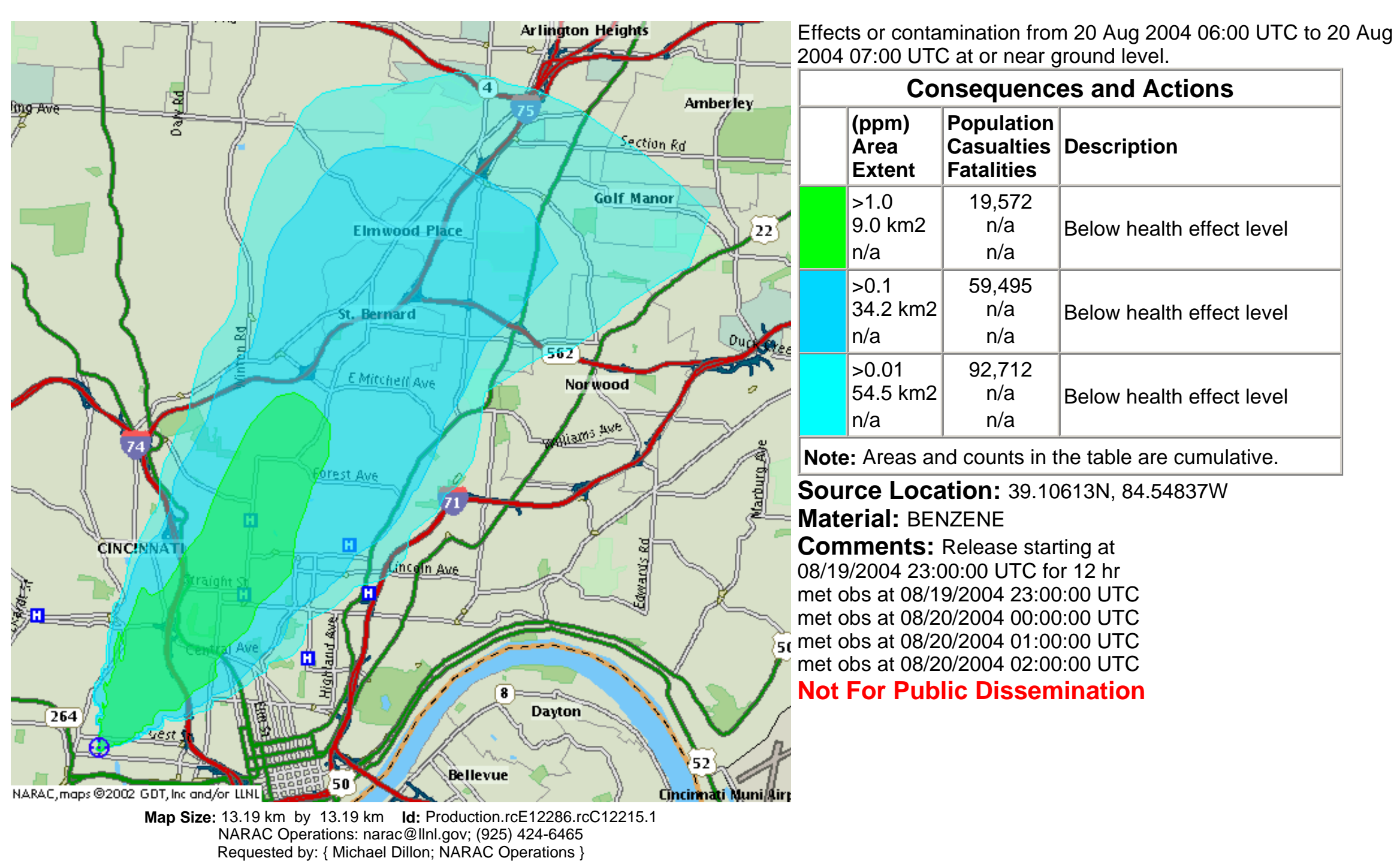




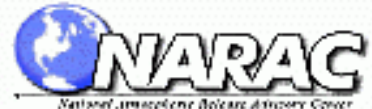

Max 10-min Air Conc over $1 \mathrm{hr}$ at 20 Aug 0800 UTC

Set 2: Hourly 10 min Peak Averages Automated Report - Actual Release

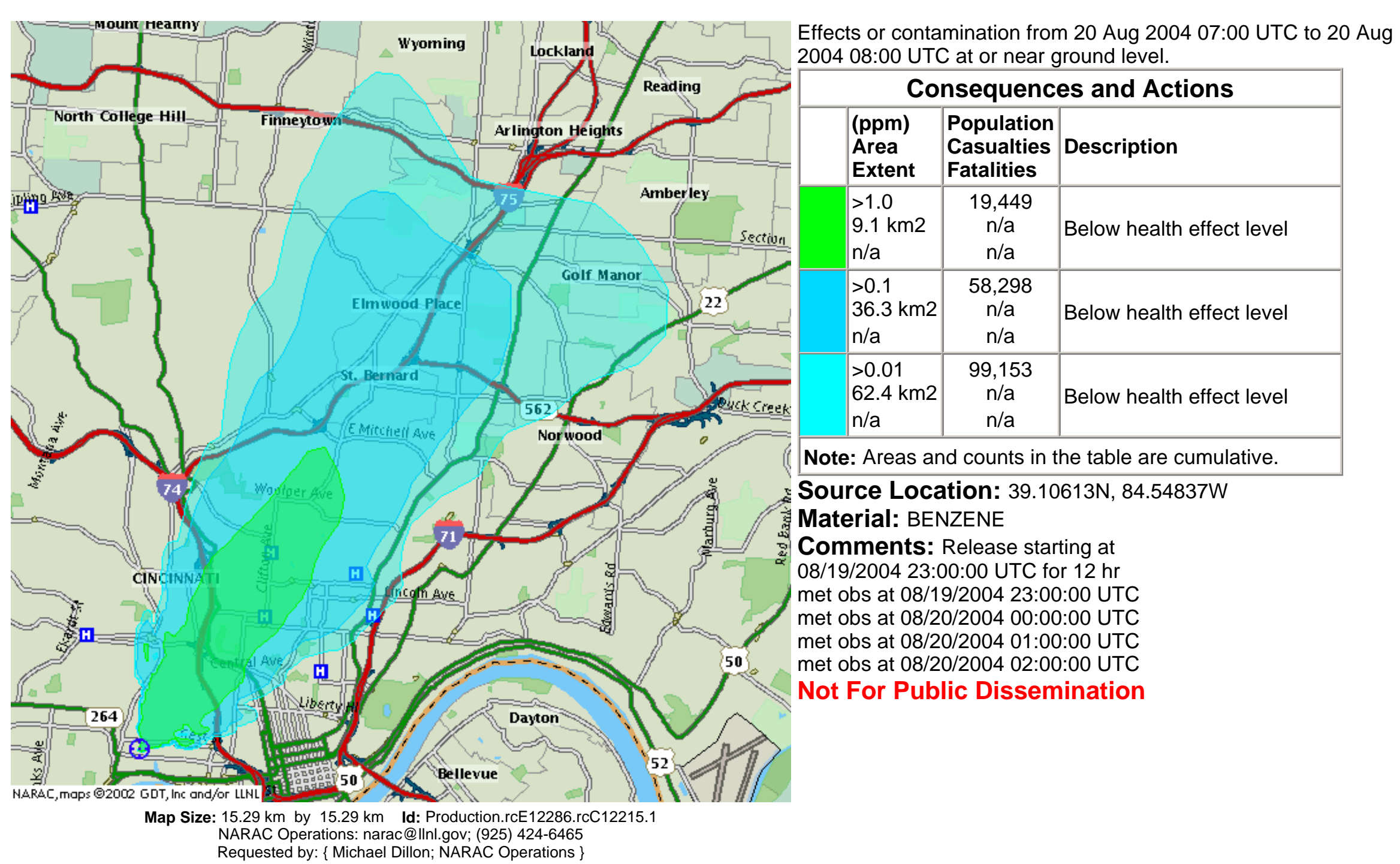




\section{QNingas}

Max 10-min Air Conc over $1 \mathrm{hr}$ at 20 Aug 0900 UTC

Set 2: Hourly 10 min Peak Averages Automated Report - Actual Release

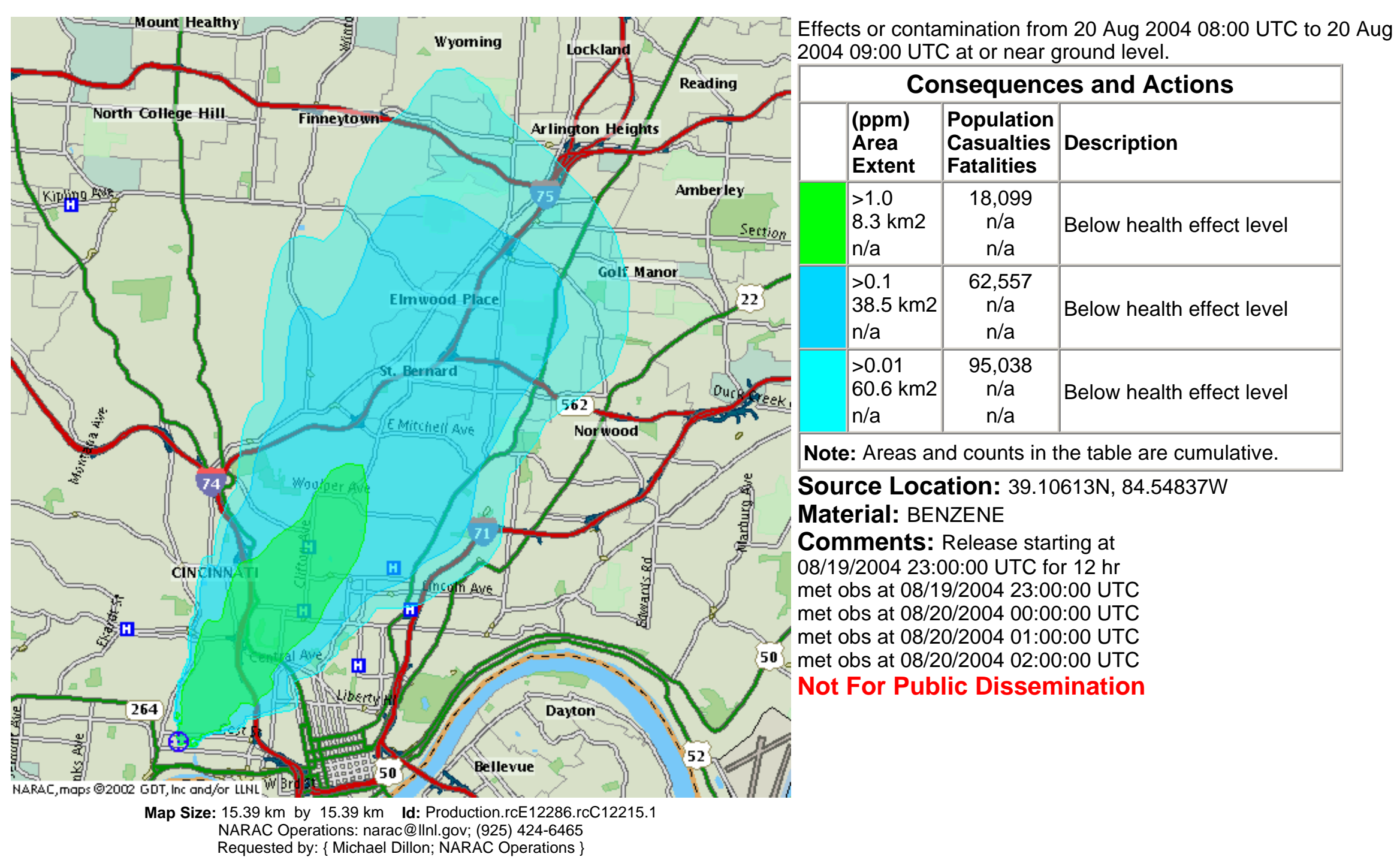




\section{QNoveras}

Max 10-min Air Conc over $1 \mathrm{hr}$ at 20Aug 1000 UTC

Set 2: Hourly 10 min Peak Averages Automated Report - Actual Release

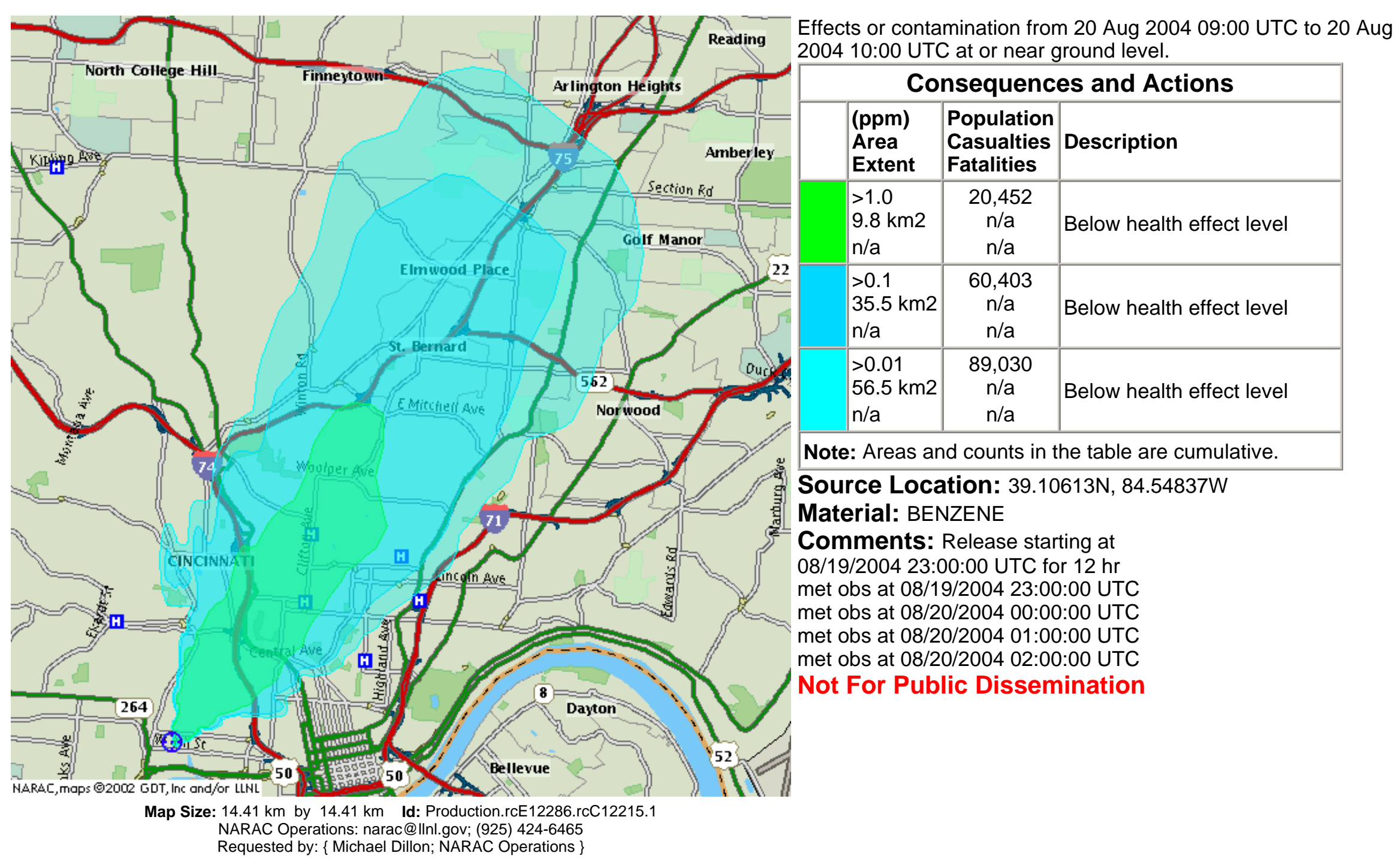




\section{Qingeas}

Max 10-min Air Conc over $1 \mathrm{hr}$ at 20Aug 1100 UTC

Set 2: Hourly 10 min Peak Averages Automated Report - Actual Release

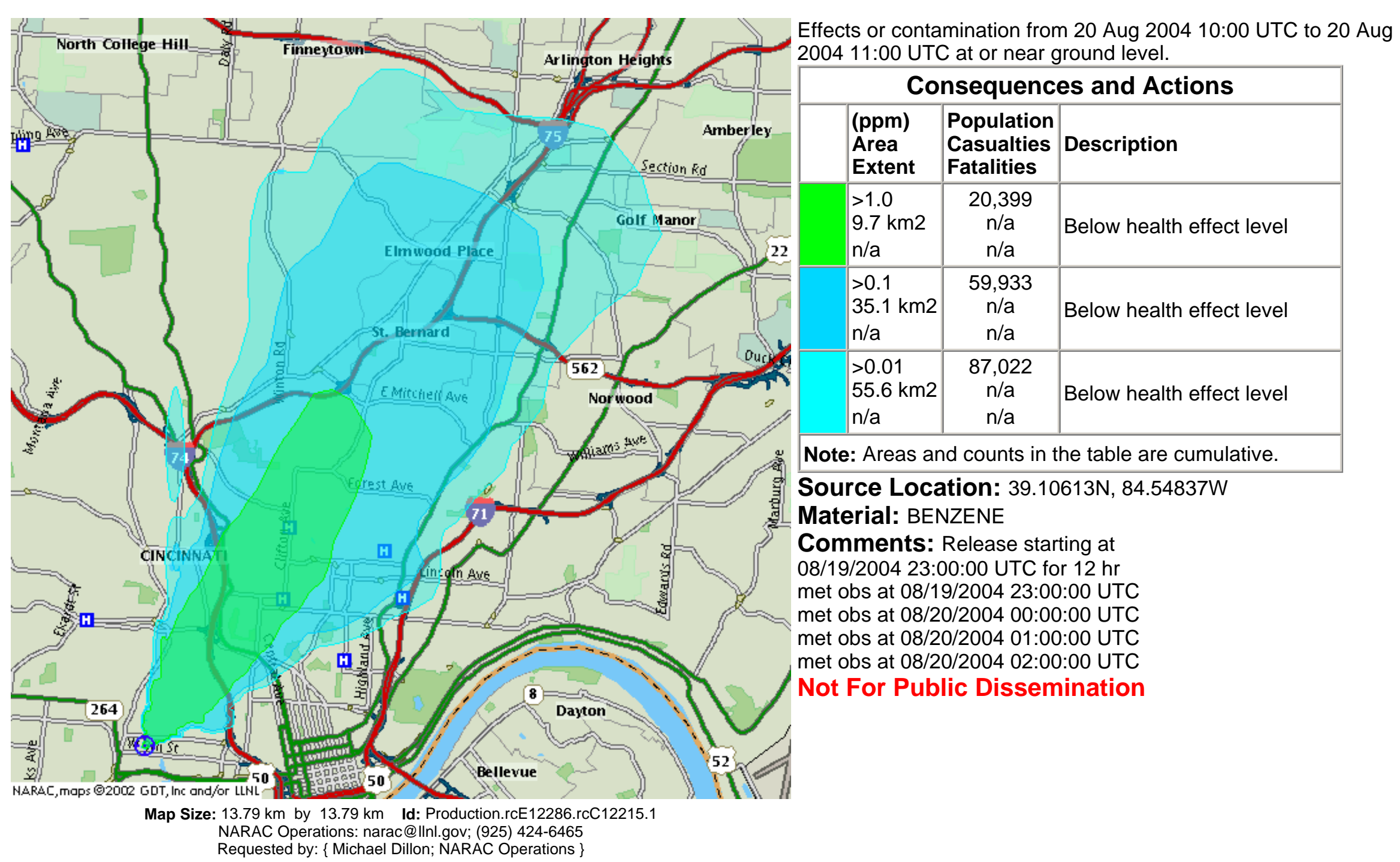




\section{Max 10-min Air Conc over $1 \mathrm{hr}$ at 20Aug 0000 UTC}

Set 3: Benzene off at 2am EDT Benzene off at 2am EDT - Actual Release

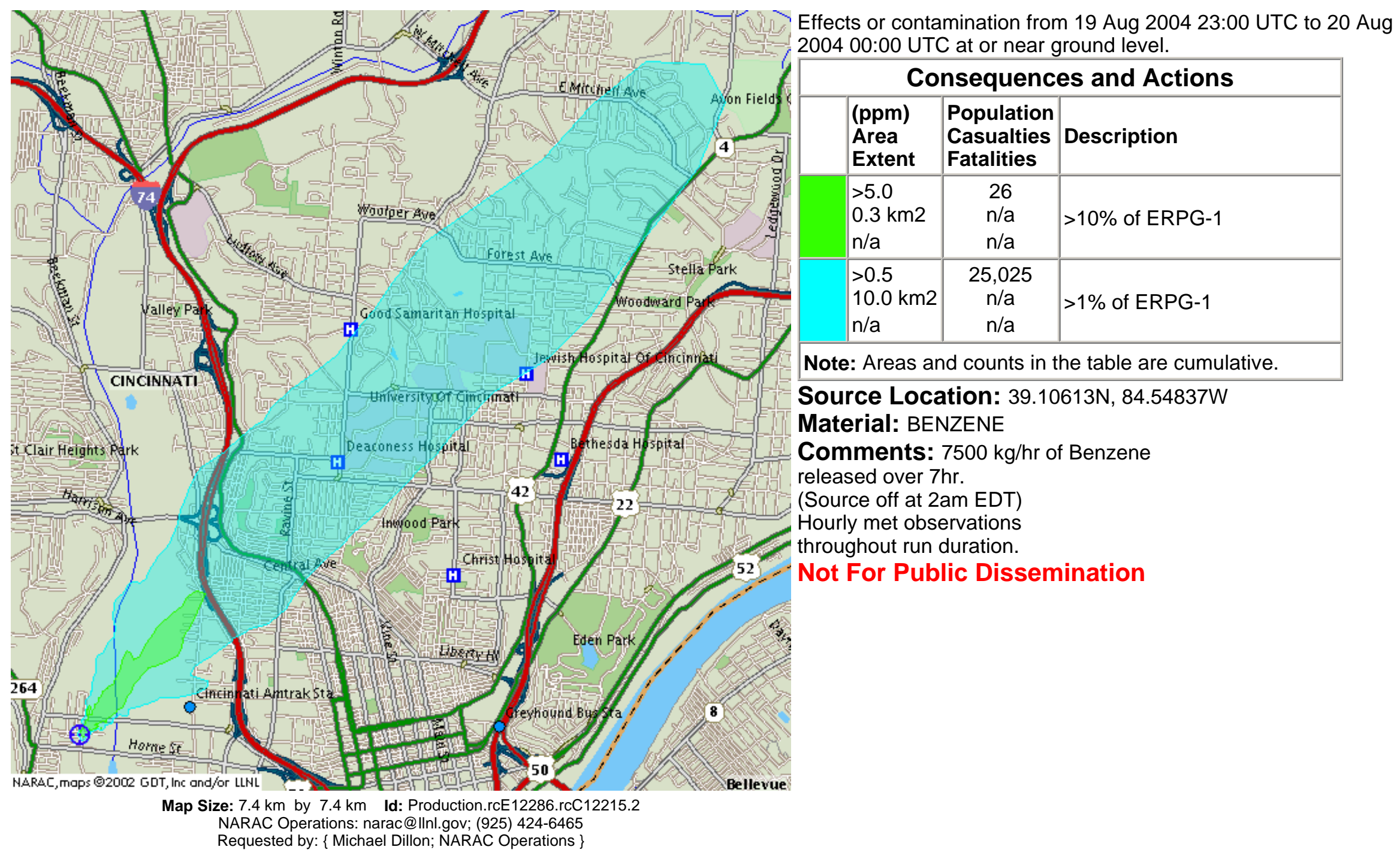




\section{Max 10-min Air Conc over 1 hr at 20Aug 0100 UTC}

Set 3: Benzene off at 2am EDT Benzene off at 2am EDT - Actual Release

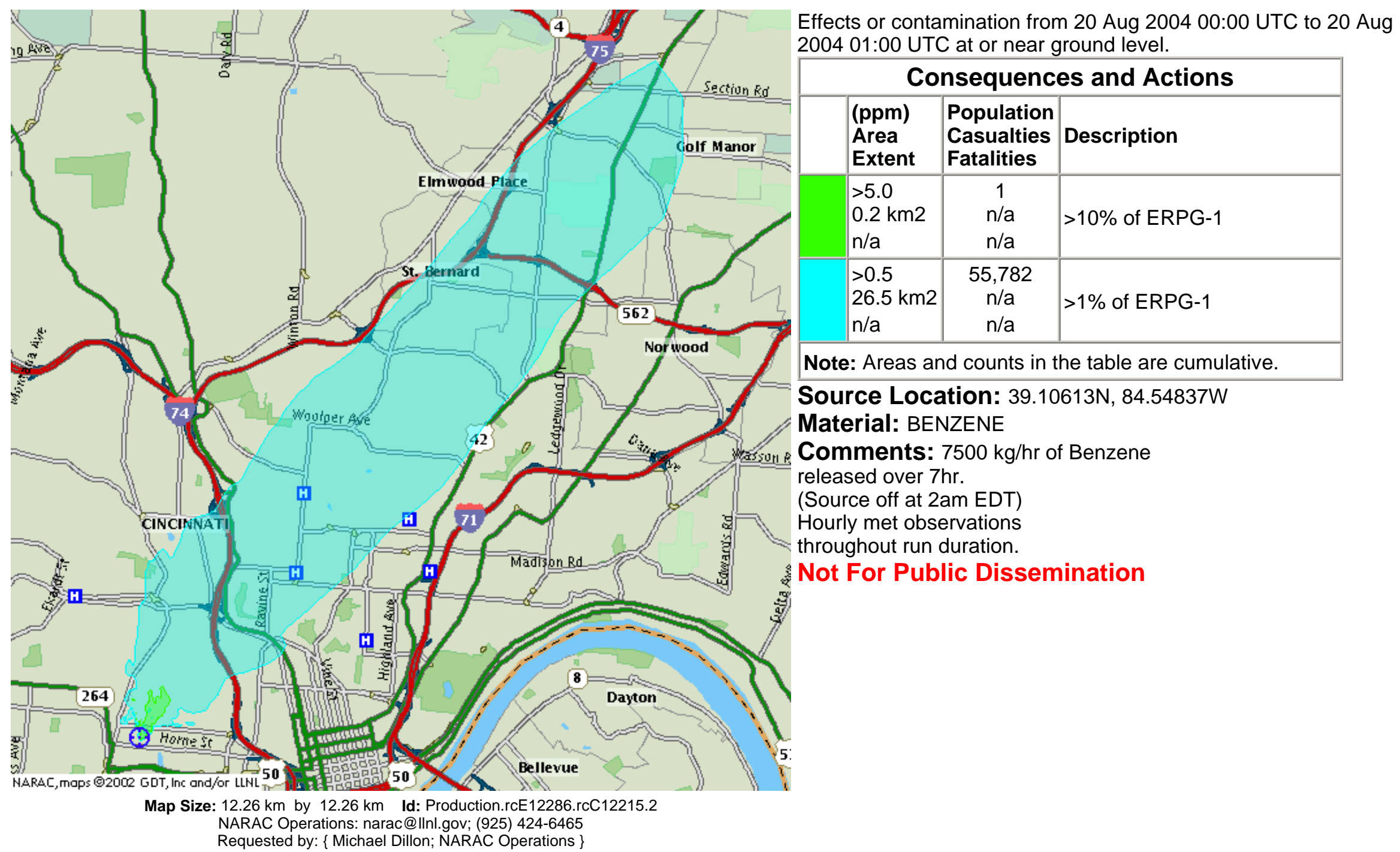




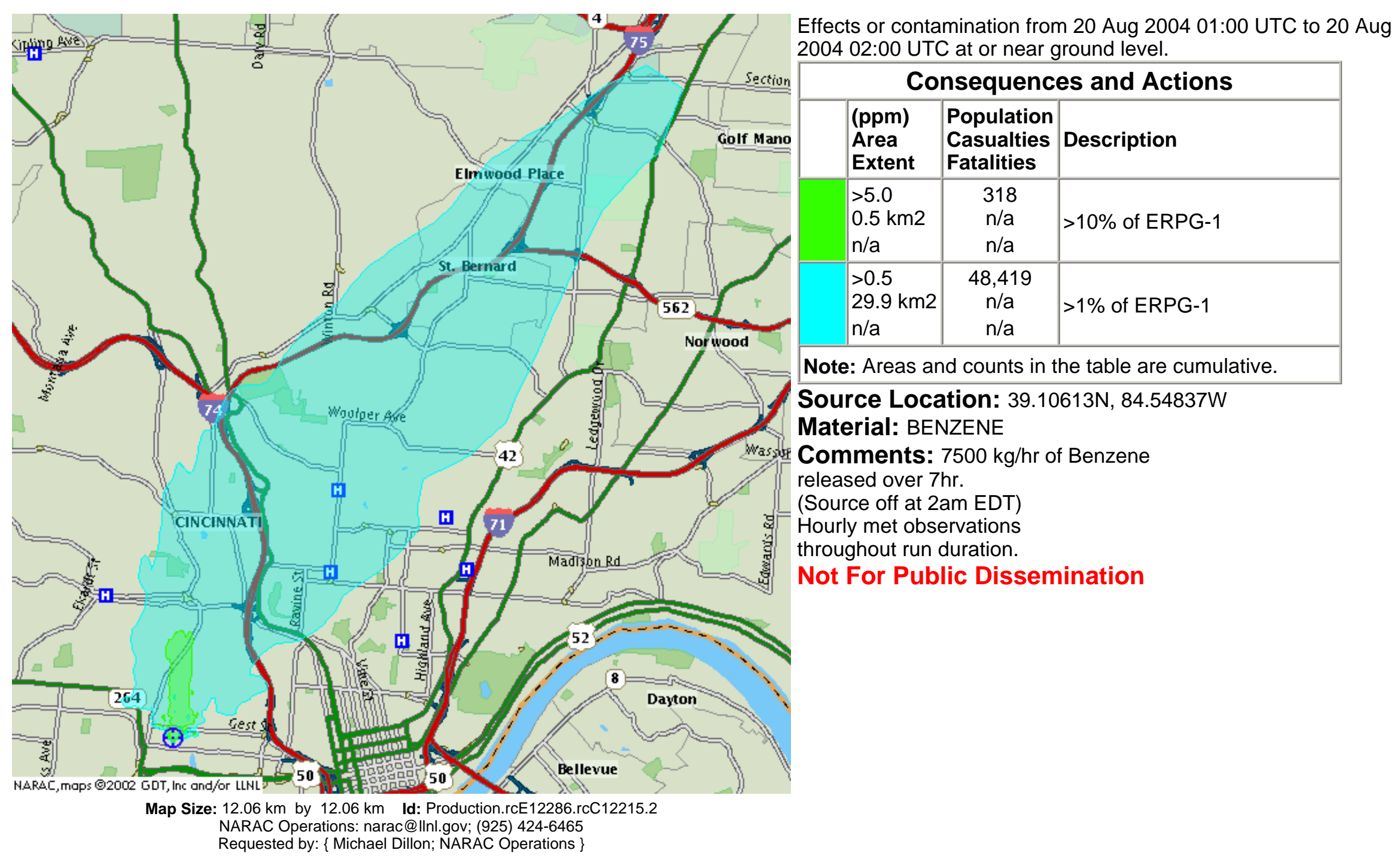




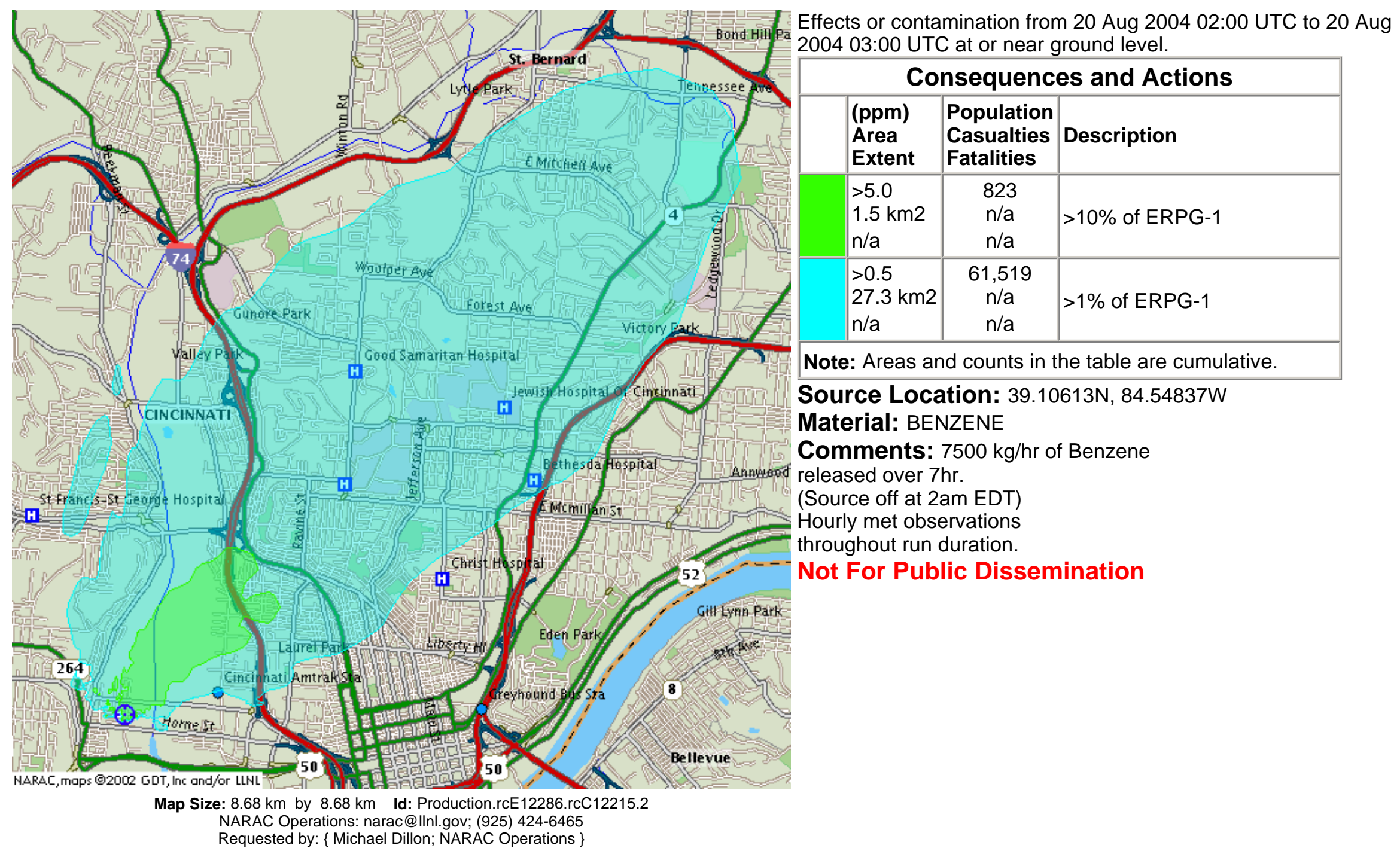




\section{Max 10-min Air Conc over $1 \mathrm{hr}$ at 20Aug 0400 UTC}

Set 3: Benzene off at 2am EDT Benzene off at 2am EDT - Actual Release

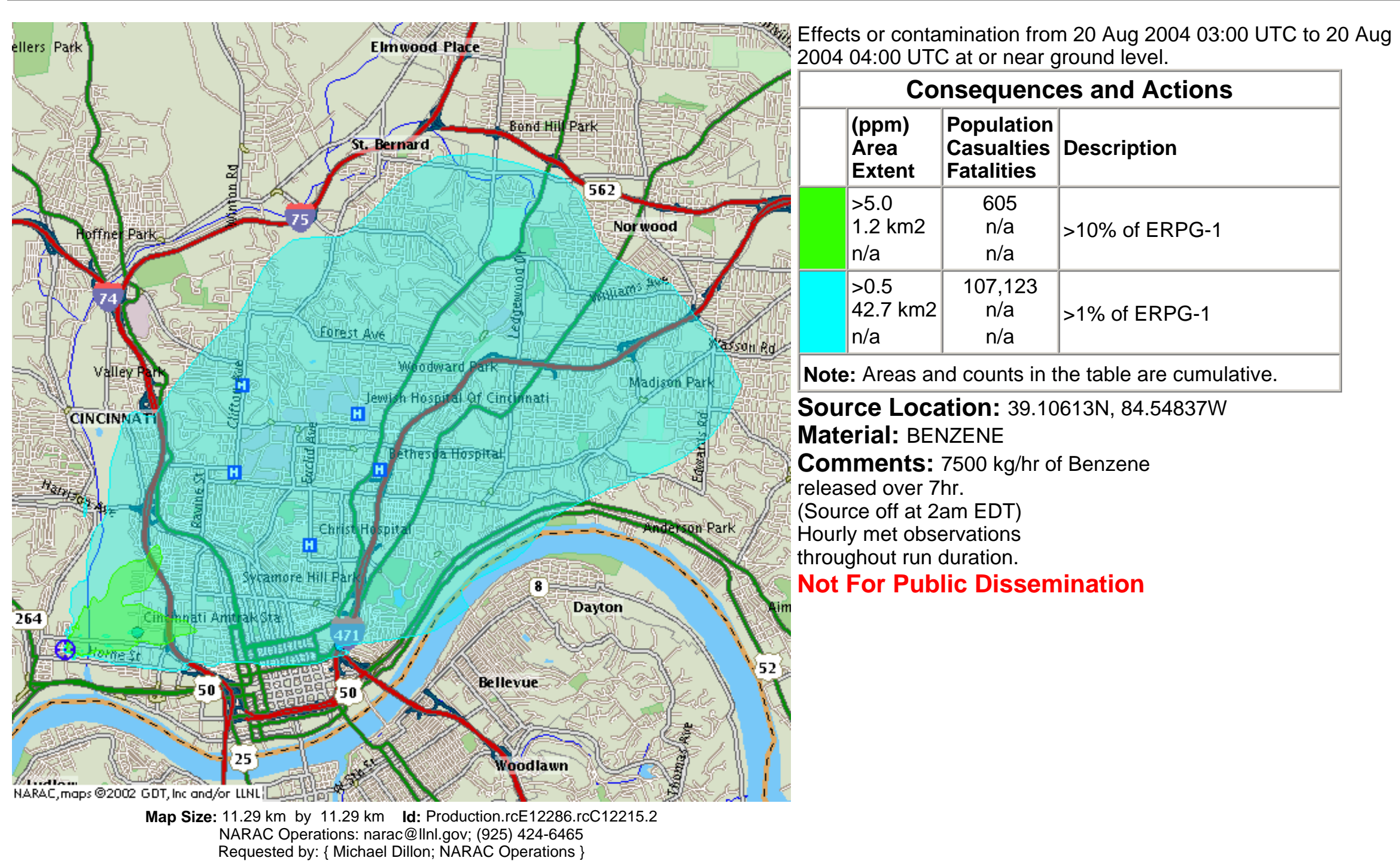




\section{Max 10-min Air Conc over $1 \mathrm{hr}$ at 20Aug 0500 UTC}

Set 3: Benzene off at 2am EDT Benzene off at 2am EDT - Actual Release

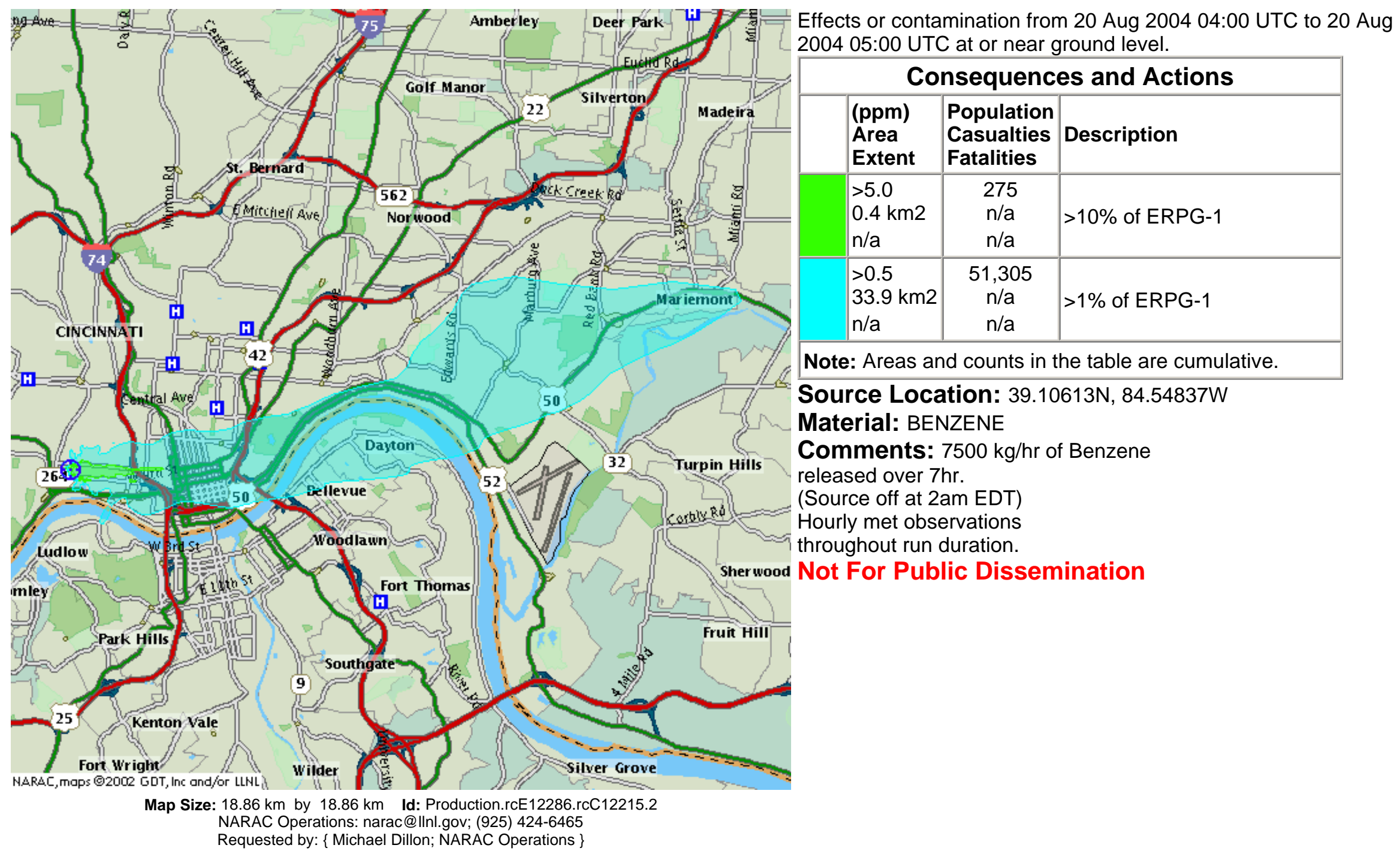




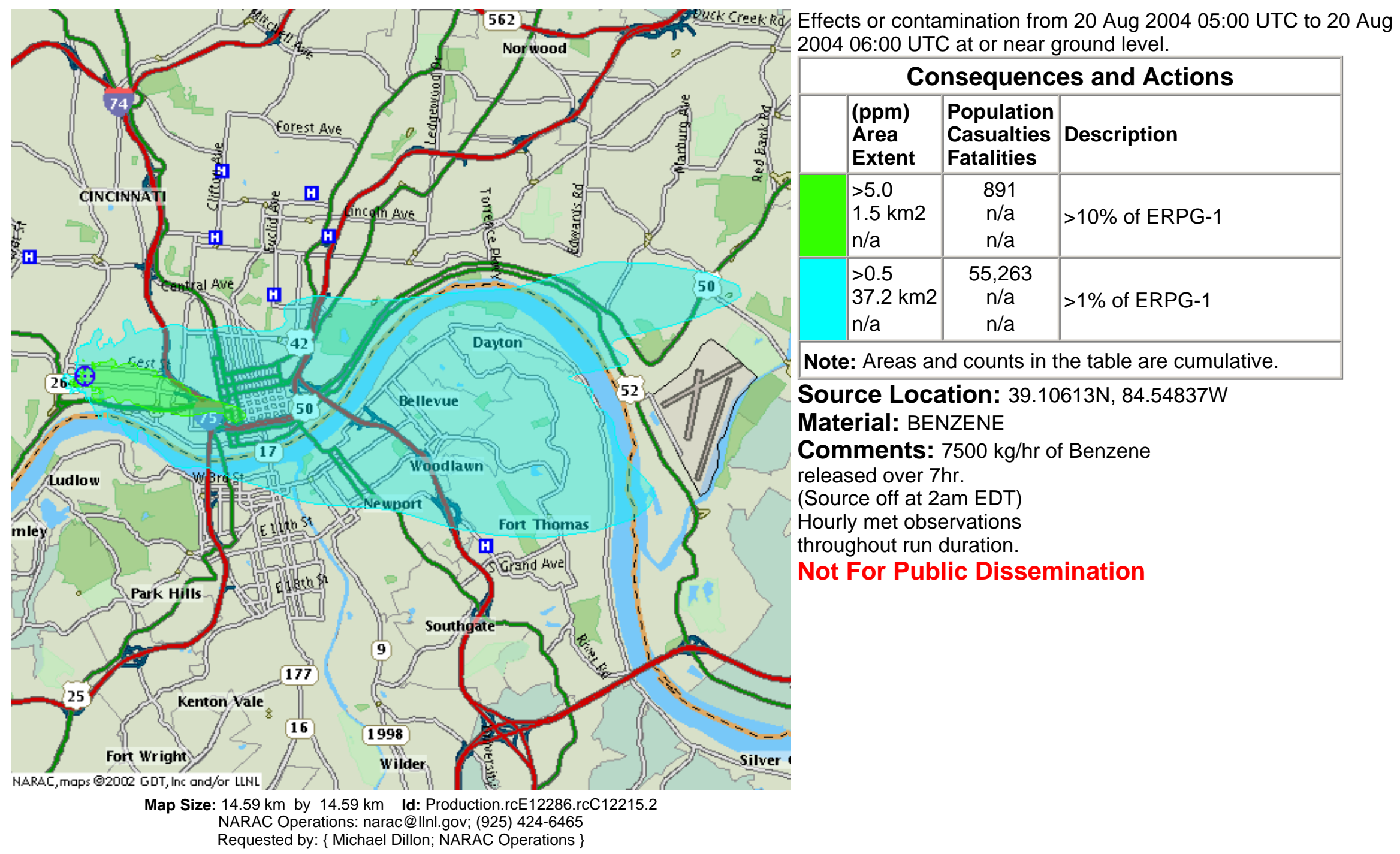




\section{QNYNOAS \\ Max 10-min Air Conc over $1 \mathrm{hr}$ at 20Aug 0700 UTC}

Set 3: Benzene off at 2am EDT Benzene off at 2am EDT - Actual Release

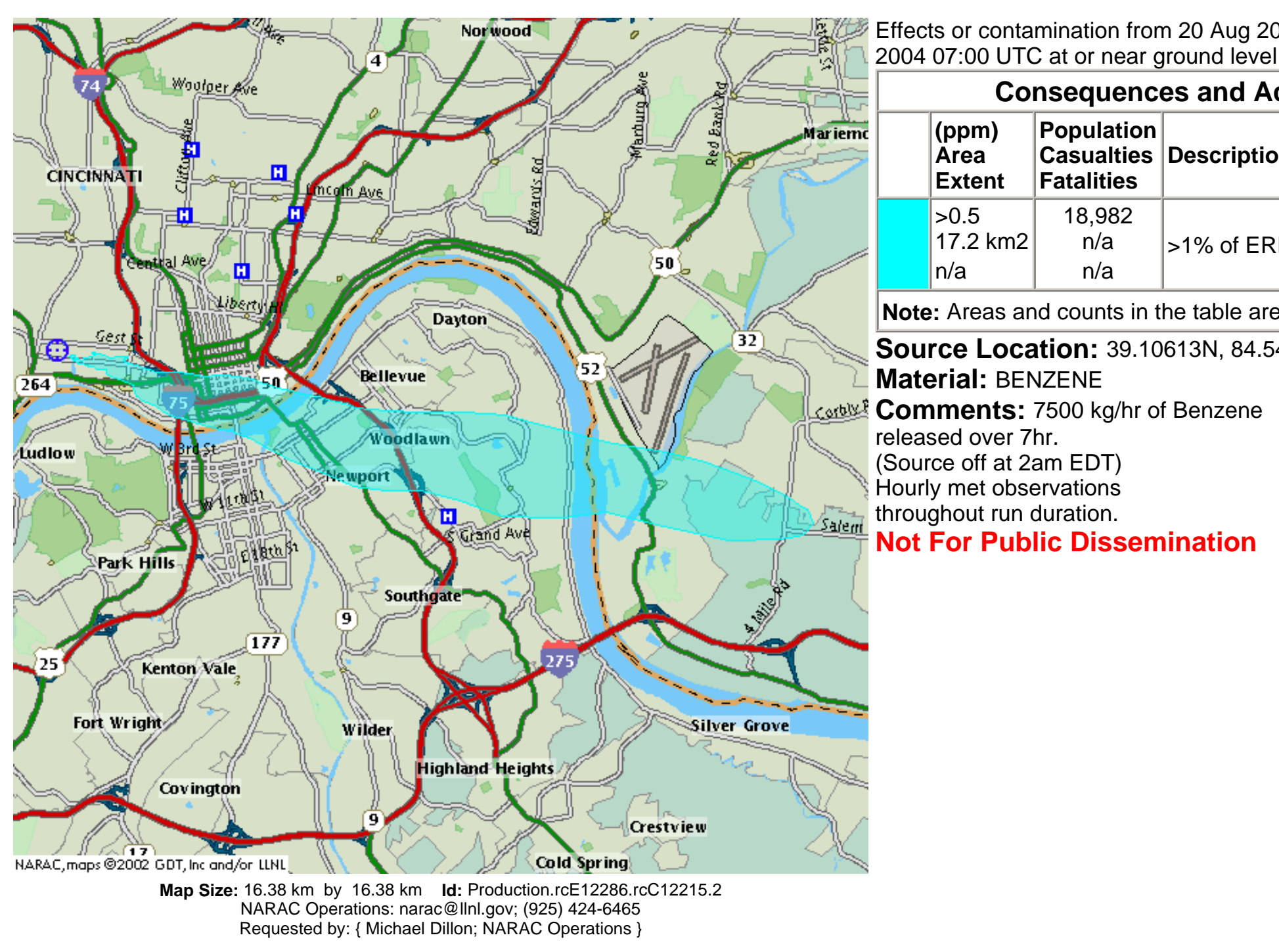


Max 10-min Air Conc ovr $1 \mathrm{hr}$ at 20Aug 1100 UTC
Set 4: Smoldering Plume scaled to measurement

(8.6e6g)

Automated Report - Actual Release

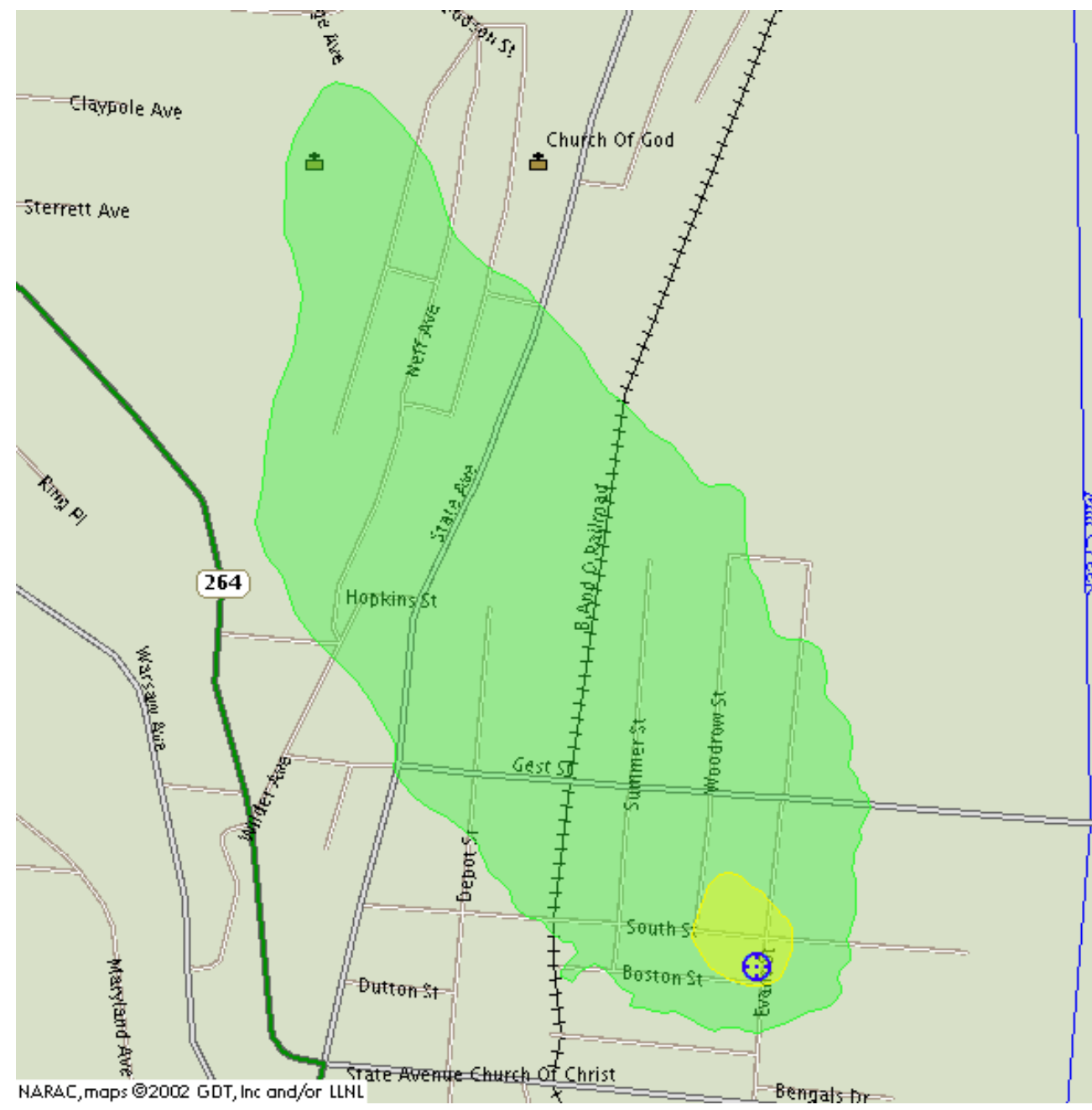

Map Size: $1.08 \mathrm{~km}$ by $1.08 \mathrm{~km} \quad$ Id: Production.rcE12286.rcC12215.3

NARAC Operations: narac@llnl.gov; (925) 424-6465

Requested by: \{ Michael Dillon; NARAC Operations \}
Effects or contamination from 20 Aug 2004 10:00 UTC to 20 Aug 2004 11:00 UTC at or near ground level.

\begin{tabular}{|l|l|c|l|}
\hline \multicolumn{4}{|c|}{ Consequences and Actions } \\
\hline \multicolumn{1}{|l|}{$\begin{array}{l}\text { (ppm) } \\
\text { Area } \\
\text { Extent }\end{array}$} & $\begin{array}{l}\text { Population } \\
\text { Casualties } \\
\text { Fatalities }\end{array}$ & Description \\
\hline$>50$ & 0 & $>$ ERPG-1: Minor reversible \\
$0.008 \mathrm{~km} 2$ & $\mathrm{n} / \mathrm{a}$ & health effects. Possible odor. \\
$\mathrm{n} / \mathrm{a}$ & $\mathrm{n} / \mathrm{a}$ & \\
\hline$>5.0$ & 278 & \\
$0.3 \mathrm{~km} 2$ & $\mathrm{n} / \mathrm{a}$ & $>10 \%$ of the ERPG -1 \\
$\mathrm{n} / \mathrm{a}$ & $\mathrm{n} / \mathrm{a}$ & \\
\hline \multicolumn{3}{|l|}{ Note: Areas and counts in the table are cumulative. } \\
\hline
\end{tabular}

Source Location: $39.10613 \mathrm{~N}, 84.54837 \mathrm{~W}$

\section{Material: BENZENE}

Comments: Release starting at

08/20/2004 10:00:00 UTC for $8 \mathrm{hr}$

gridded met at 08/20/2004 04:00:00 UTC

gridded met at 08/20/2004 05:00:00 UTC

gridded met at 08/20/2004 06:00:00 UTC

gridded met at 08/20/2004 07:00:00 UTC

Not For Public Dissemination 
Max 10-min Air Conc ovr $1 \mathrm{hr}$ at 20Aug 1200 UTC
Set 4: Smoldering Plume scaled to measurement

(8.6e6g)

Automated Report - Actual Release

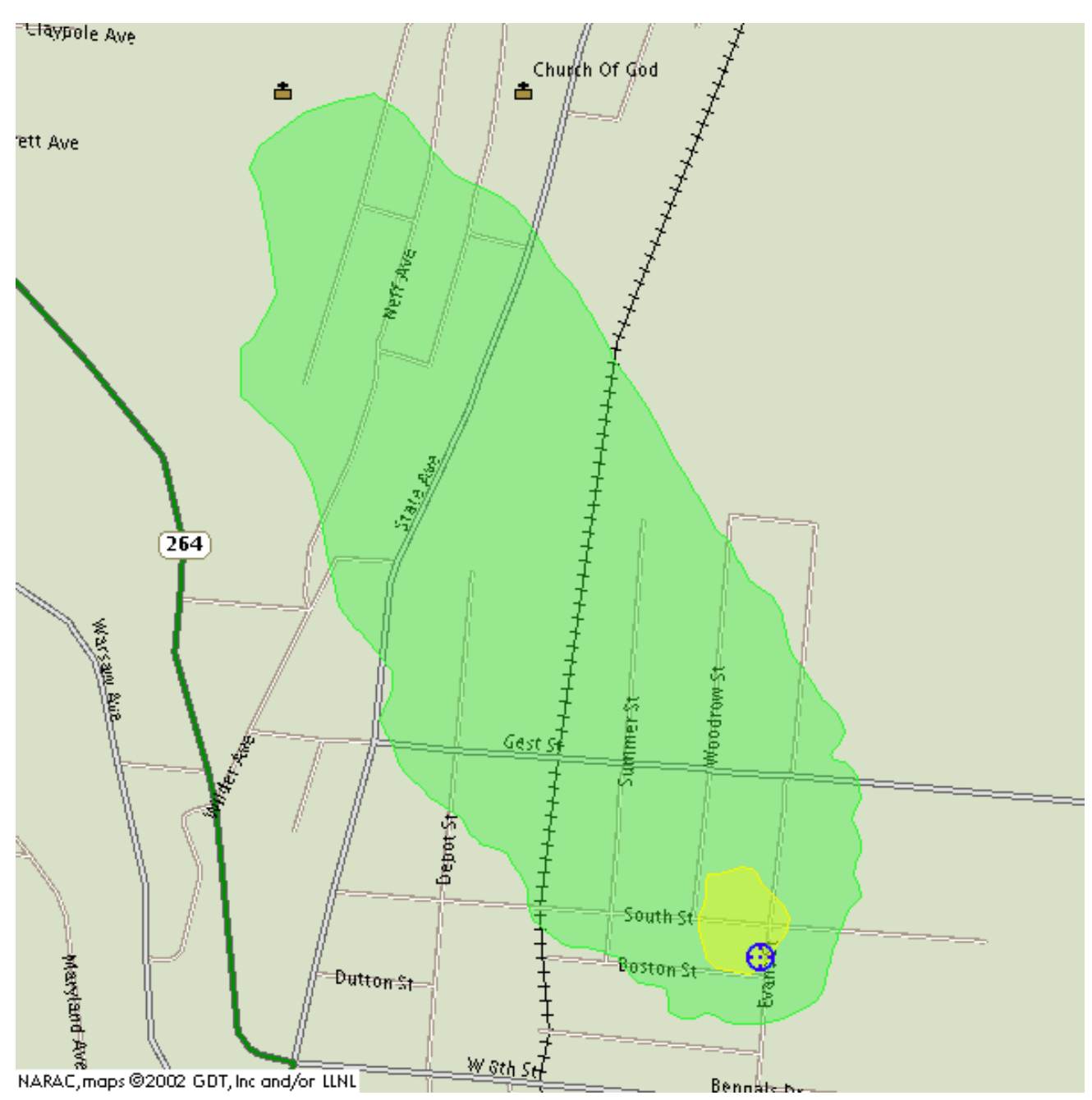

Map Size: $985.94 \mathrm{~m}$ by $985.94 \mathrm{~m}$ Id: Production.rcE12286.rcC12215.3

NARAC Operations: narac@llnl.gov; (925) 424-6465

Requested by: \{ Michael Dillon; NARAC Operations \}
Effects or contamination from 20 Aug 2004 11:00 UTC to 20 Aug 2004 12:00 UTC at or near ground level.

\begin{tabular}{|l|l|c|l|}
\hline \multicolumn{3}{|c|}{ Consequences and Actions } \\
\hline \multicolumn{1}{|c|}{$\begin{array}{l}\text { (ppm) } \\
\text { Area } \\
\text { Extent }\end{array}$} & $\begin{array}{l}\text { Population } \\
\text { Casualties } \\
\text { Fatalities }\end{array}$ & Description \\
\hline$>50$ & 0 & $>$ ERPG-1: Minor reversible \\
$0.006 \mathrm{~km} 2$ & $\mathrm{n} / \mathrm{a}$ & health effects. Possible odor. \\
$\mathrm{n} / \mathrm{a}$ & $\mathrm{n} / \mathrm{a}$ & \\
\hline$>5.0$ & 251 & \\
$0.3 \mathrm{~km} 2$ & $\mathrm{n} / \mathrm{a}$ & $>10 \%$ of the ERPG -1 \\
$\mathrm{n} / \mathrm{a}$ & $\mathrm{n} / \mathrm{a}$ & \\
\hline
\end{tabular}

Source Location: $39.10613 \mathrm{~N}, 84.54837 \mathrm{~W}$

\section{Material: BENZENE}

Comments: Release starting at

08/20/2004 10:00:00 UTC for $8 \mathrm{hr}$

gridded met at 08/20/2004 04:00:00 UTC

gridded met at 08/20/2004 05:00:00 UTC

gridded met at 08/20/2004 06:00:00 UTC

gridded met at 08/20/2004 07:00:00 UTC

Not For Public Dissemination 
Max 10-min Air Conc ovr $1 \mathrm{hr}$ at 20Aug 1300 UTC
Set 4: Smoldering Plume scaled to measurement

(8.6e6g)

Automated Report - Actual Release

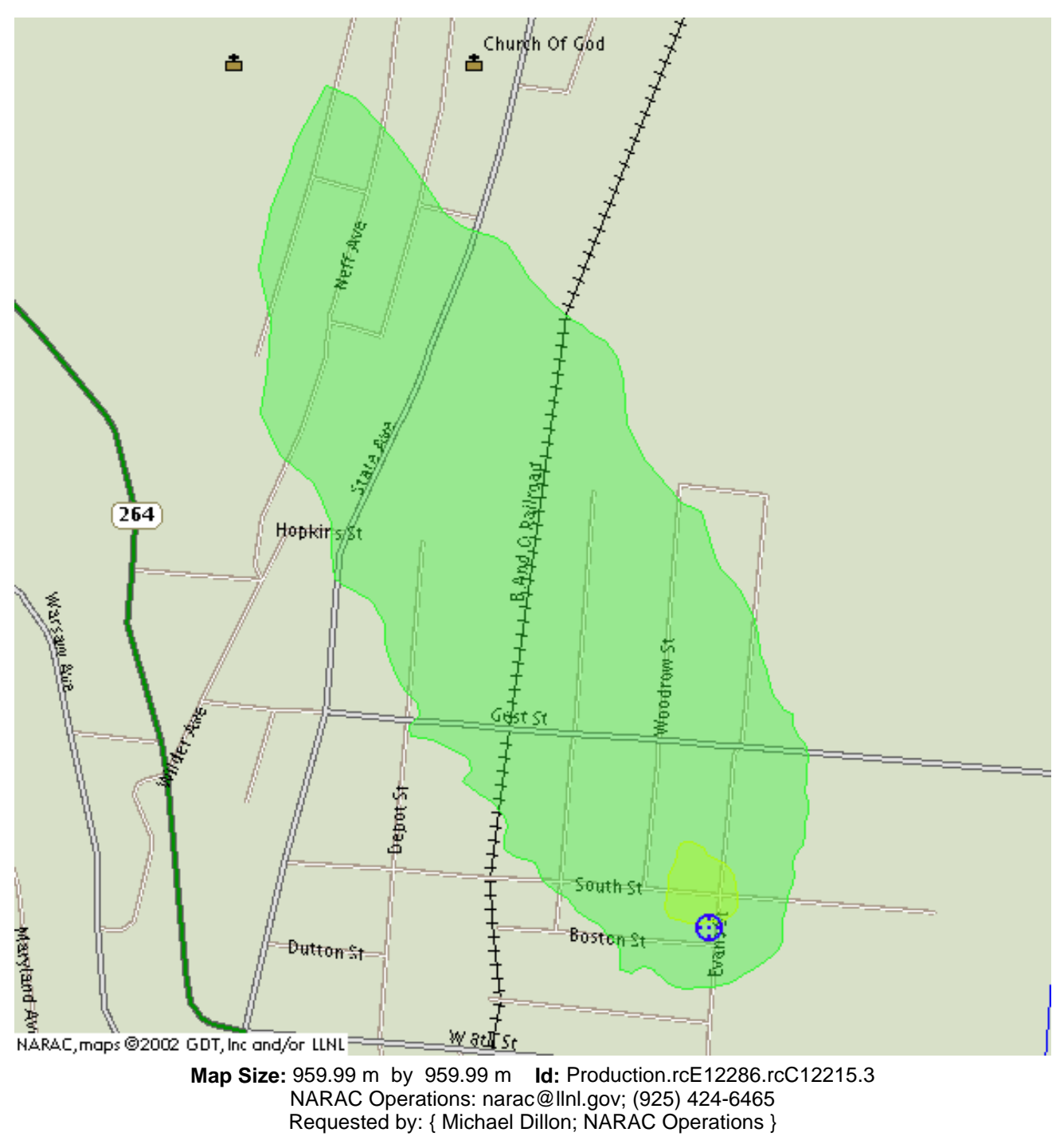

Effects or contamination from 20 Aug 2004 12:00 UTC to 20 Aug 2004 13:00 UTC at or near ground level.

\begin{tabular}{|l|l|c|l|}
\hline \multicolumn{3}{|c|}{ Consequences and Actions } \\
\hline \multicolumn{1}{|l|}{$\begin{array}{l}\text { (ppm) } \\
\text { Area } \\
\text { Extent }\end{array}$} & $\begin{array}{l}\text { Population } \\
\text { Casualties } \\
\text { Fatalities }\end{array}$ & Description \\
\hline$>50$ & 0 & $>$ ERPG-1: Minor reversible \\
$0.004 \mathrm{~km} 2$ & $\mathrm{n} / \mathrm{a}$ & health effects. Possible odor. \\
$\mathrm{n} / \mathrm{a}$ & $\mathrm{n} / \mathrm{a}$ & \\
\hline$>5.0$ & 199 & \\
$0.2 \mathrm{~km} 2$ & $\mathrm{n} / \mathrm{a}$ & $>10 \%$ of the ERPG -1 \\
$\mathrm{n} / \mathrm{a}$ & $\mathrm{n} / \mathrm{a}$ & \\
\hline \multicolumn{3}{|c|}{ Note: Areas and counts in the table are cumulative. } \\
\hline
\end{tabular}

Source Location: $39.10613 \mathrm{~N}, 84.54837 \mathrm{~W}$

\section{Material: BENZENE}

Comments: Release starting at

08/20/2004 10:00:00 UTC for $8 \mathrm{hr}$

gridded met at 08/20/2004 04:00:00 UTC

gridded met at 08/20/2004 05:00:00 UTC

gridded met at 08/20/2004 06:00:00 UTC

gridded met at 08/20/2004 07:00:00 UTC

Not For Public Dissemination 
Max 10-min Air Conc ovr $1 \mathrm{hr}$ at 20Aug 1400 UTC
Set 4: Smoldering Plume scaled to measurement

(8.6e6g)

Automated Report - Actual Release

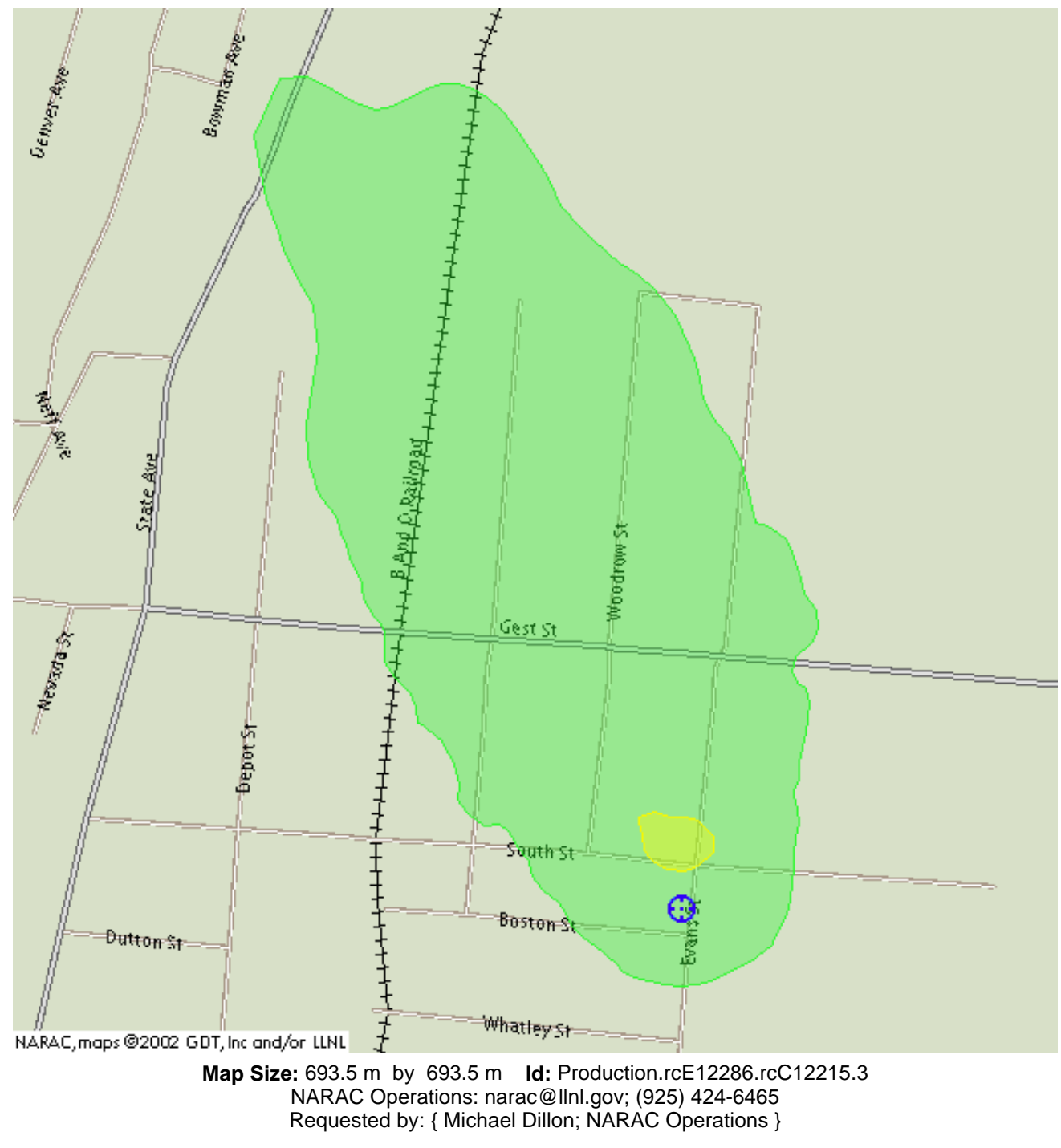

Effects or contamination from 20 Aug 2004 13:00 UTC to 20 Aug 2004 14:00 UTC at or near ground level.

\begin{tabular}{|l|l|c|l|}
\hline \multicolumn{4}{|c|}{ Consequences and Actions } \\
\hline \multicolumn{1}{|l|}{$\begin{array}{l}\text { (ppm) } \\
\text { Area } \\
\text { Extent }\end{array}$} & $\begin{array}{l}\text { Population } \\
\text { Casualties } \\
\text { Fatalities }\end{array}$ & Description \\
\hline$>50$ & 1 & $>$ ERPG-1: Minor reversible \\
$0.001 \mathrm{~km} 2$ & $\mathrm{n} / \mathrm{a}$ & health effects. Possible odor. \\
$\mathrm{n} / \mathrm{a}$ & $\mathrm{n} / \mathrm{a}$ & \\
\hline$>5.0$ & 159 & \\
$0.1 \mathrm{~km} 2$ & $\mathrm{n} / \mathrm{a}$ & $>10 \%$ of the ERPG -1 \\
$\mathrm{n} / \mathrm{a}$ & $\mathrm{n} / \mathrm{a}$ & \\
\hline \multicolumn{3}{|c|}{ Note: Areas and counts in the table are cumulative. } \\
\hline
\end{tabular}

Source Location: $39.10613 \mathrm{~N}, 84.54837 \mathrm{~W}$

\section{Material: BENZENE}

Comments: Release starting at

08/20/2004 10:00:00 UTC for $8 \mathrm{hr}$ gridded met at 08/20/2004 04:00:00 UTC gridded met at 08/20/2004 05:00:00 UTC gridded met at 08/20/2004 06:00:00 UTC gridded met at 08/20/2004 07:00:00 UTC Not For Public Dissemination 
Max 10-min Air Conc ovr $1 \mathrm{hr}$ at 20Aug 1500 UTC
Set 4: Smoldering Plume scaled to measurement

(8.6e6g)

Automated Report - Actual Release

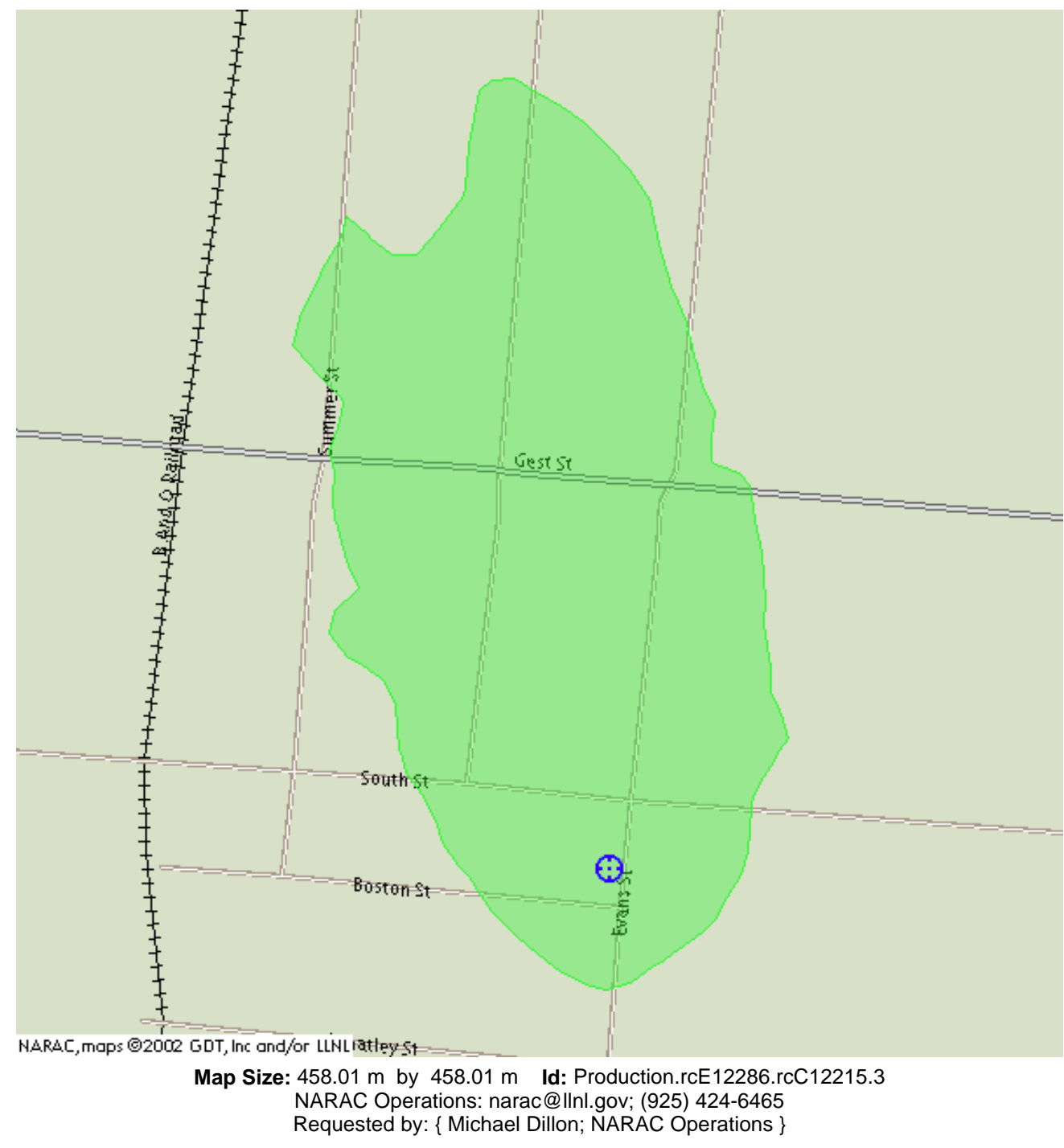

Effects or contamination from 20 Aug 2004 14:00 UTC to 20 Aug 2004 15:00 UTC at or near ground level.

\begin{tabular}{|l|l|c|c|}
\hline \multicolumn{3}{|c|}{ Consequences and Actions } \\
\hline \multicolumn{1}{|l|}{$\begin{array}{l}\text { (ppm) } \\
\text { Area } \\
\text { Extent }\end{array}$} & $\begin{array}{l}\text { Population } \\
\text { Casualties } \\
\text { Fatalities }\end{array}$ & Description \\
\hline$>5.0$ & 29 & \\
$0.05 \mathrm{~km} 2$ & $\mathrm{n} / \mathrm{a}$ & $>10 \%$ of the ERPG -1 \\
$\mathrm{n} / \mathrm{a}$ & $\mathrm{n} / \mathrm{a}$ & \\
\hline \multicolumn{2}{|c|}{ Note: Areas and counts in the table are cumulative. } \\
\hline
\end{tabular}

Source Location: $39.10613 \mathrm{~N}, 84.54837 \mathrm{~W}$

\section{Material: BENZENE}

Comments: Release starting at

08/20/2004 10:00:00 UTC for $8 \mathrm{hr}$

gridded met at 08/20/2004 04:00:00 UTC

gridded met at 08/20/2004 05:00:00 UTC

gridded met at 08/20/2004 06:00:00 UTC

gridded met at 08/20/2004 07:00:00 UTC

Not For Public Dissemination 


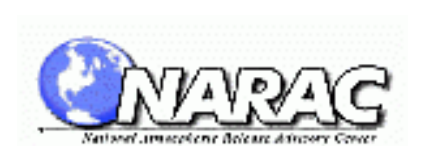

Max 10-min Air Conc ovr $1 \mathrm{hr}$ at 20Aug 1600 UTC

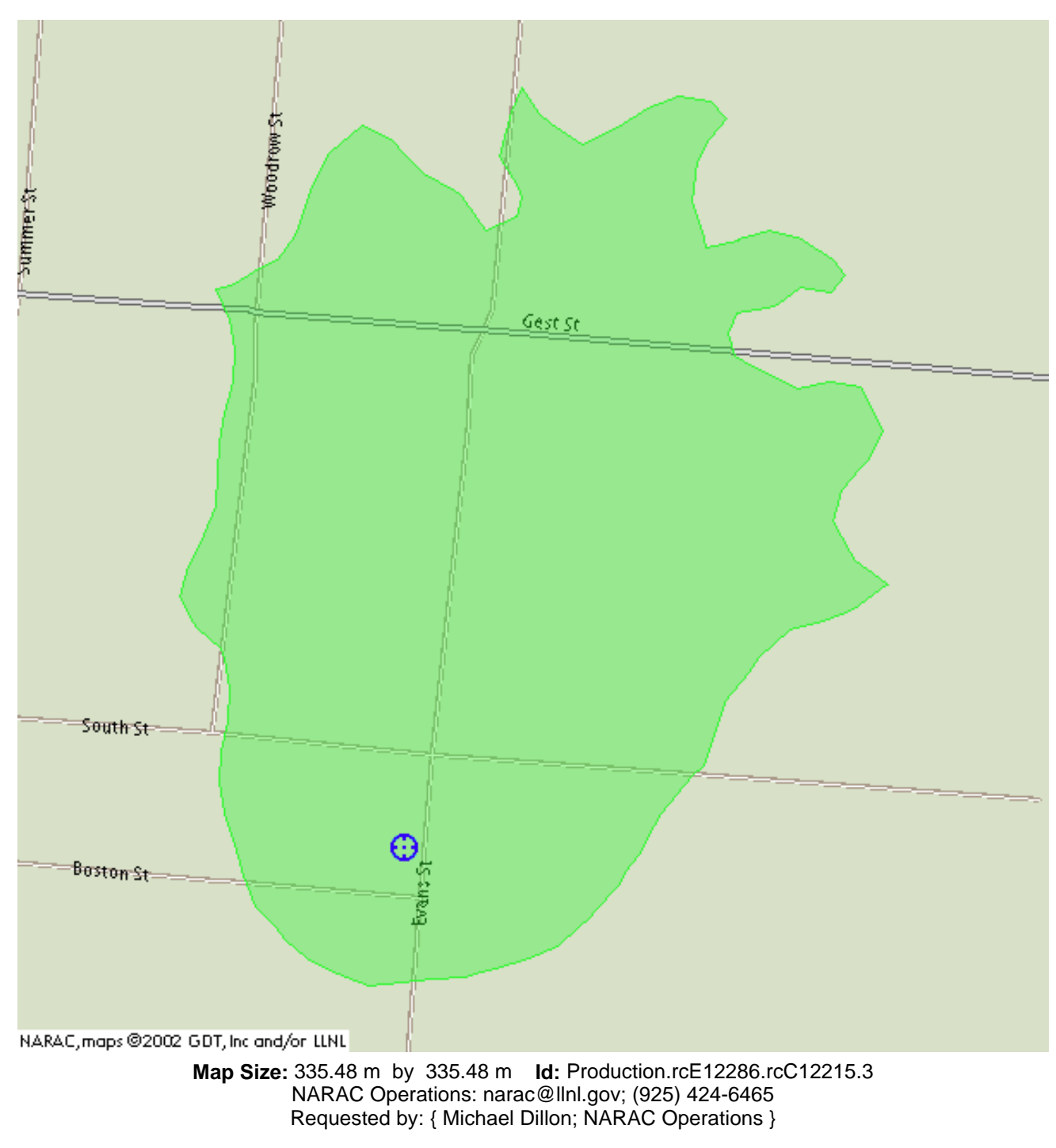

Set 4: Smoldering Plume scaled to measurement

(8.6e6g)

Automated Report - Actual Release

Effects or contamination from 20 Aug 2004 15:00 UTC to 20 Aug 2004 16:00 UTC at or near ground level.

\begin{tabular}{|l|l|l|l|}
\hline \multicolumn{3}{|c|}{ Consequences and Actions } \\
\hline \multicolumn{1}{|l|}{$\begin{array}{l}\text { (ppm) } \\
\text { Area } \\
\text { Extent }\end{array}$} & $\begin{array}{l}\text { Population } \\
\text { Casualties } \\
\text { Fatalities }\end{array}$ & Description \\
\hline$>5.0$ & 32 & \\
$0.04 \mathrm{~km} 2$ & $\mathrm{n} / \mathrm{a}$ & $>10 \%$ of the ERPG -1 \\
$\mathrm{n} / \mathrm{a}$ & $\mathrm{n} / \mathrm{a}$ & \\
\hline \multicolumn{3}{|l|}{ Note: Areas and counts in the table are cumulative. } \\
\hline
\end{tabular}

Source Location: 39.10613N, 84.54837W

Material: BENZENE

Comments: Release starting at

08/20/2004 10:00:00 UTC for $8 \mathrm{hr}$

gridded met at 08/20/2004 04:00:00 UTC

gridded met at 08/20/2004 05:00:00 UTC

gridded met at 08/20/2004 06:00:00 UTC

gridded met at 08/20/2004 07:00:00 UTC

Not For Public Dissemination 


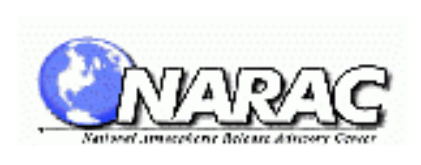

Max 10-min Air Conc ovr $1 \mathrm{hr}$ at 20Aug 1700 UTC

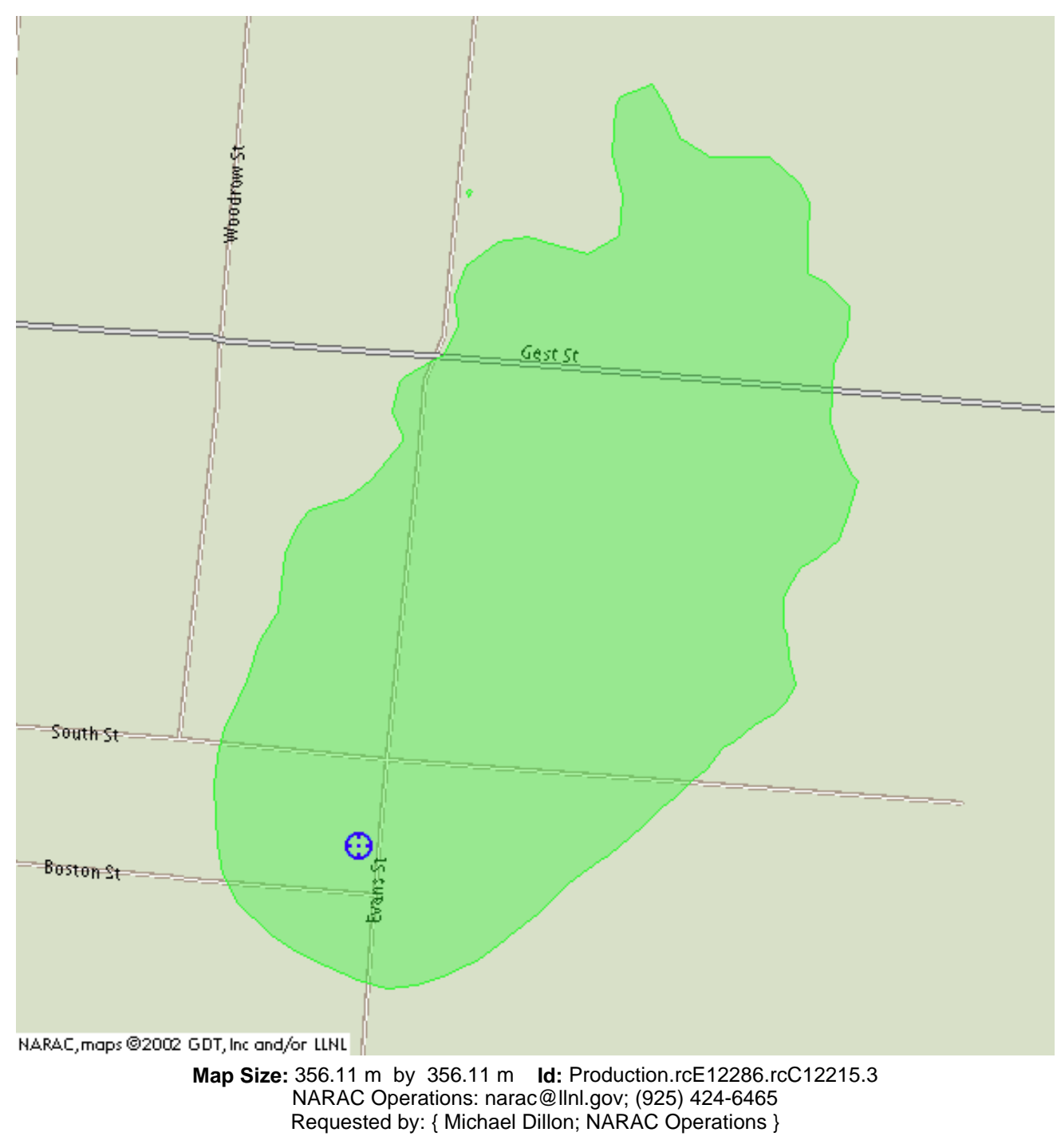

Set 4: Smoldering Plume scaled to measurement

(8.6e6g)

Automated Report - Actual Release

Effects or contamination from 20 Aug 2004 16:00 UTC to 20 Aug 2004 17:00 UTC at or near ground level.

\begin{tabular}{|l|l|l|l|}
\hline \multicolumn{3}{|c|}{ Consequences and Actions } \\
\hline \multicolumn{1}{|l|}{$\begin{array}{l}\text { (ppm) } \\
\text { Area } \\
\text { Extent }\end{array}$} & $\begin{array}{l}\text { Population } \\
\text { Casualties } \\
\text { Fatalities }\end{array}$ & Description \\
\hline$>5.0$ & 27 & \\
$0.04 \mathrm{~km} 2$ & $\mathrm{n} / \mathrm{a}$ & $>10 \%$ of the ERPG -1 \\
$\mathrm{n} / \mathrm{a}$ & $\mathrm{n} / \mathrm{a}$ & \\
\hline \multicolumn{3}{|l|}{ Note: Areas and counts in the table are cumulative. } \\
\hline
\end{tabular}

Source Location: 39.10613N, 84.54837 W

\section{Material: BENZENE}

Comments: Release starting at

08/20/2004 10:00:00 UTC for $8 \mathrm{hr}$

gridded met at 08/20/2004 04:00:00 UTC

gridded met at 08/20/2004 05:00:00 UTC

gridded met at 08/20/2004 06:00:00 UTC

gridded met at 08/20/2004 07:00:00 UTC

Not For Public Dissemination 


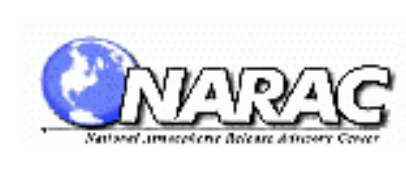

Max 10-min Air Conc ovr $1 \mathrm{hr}$ at 20Aug 1800 UTC

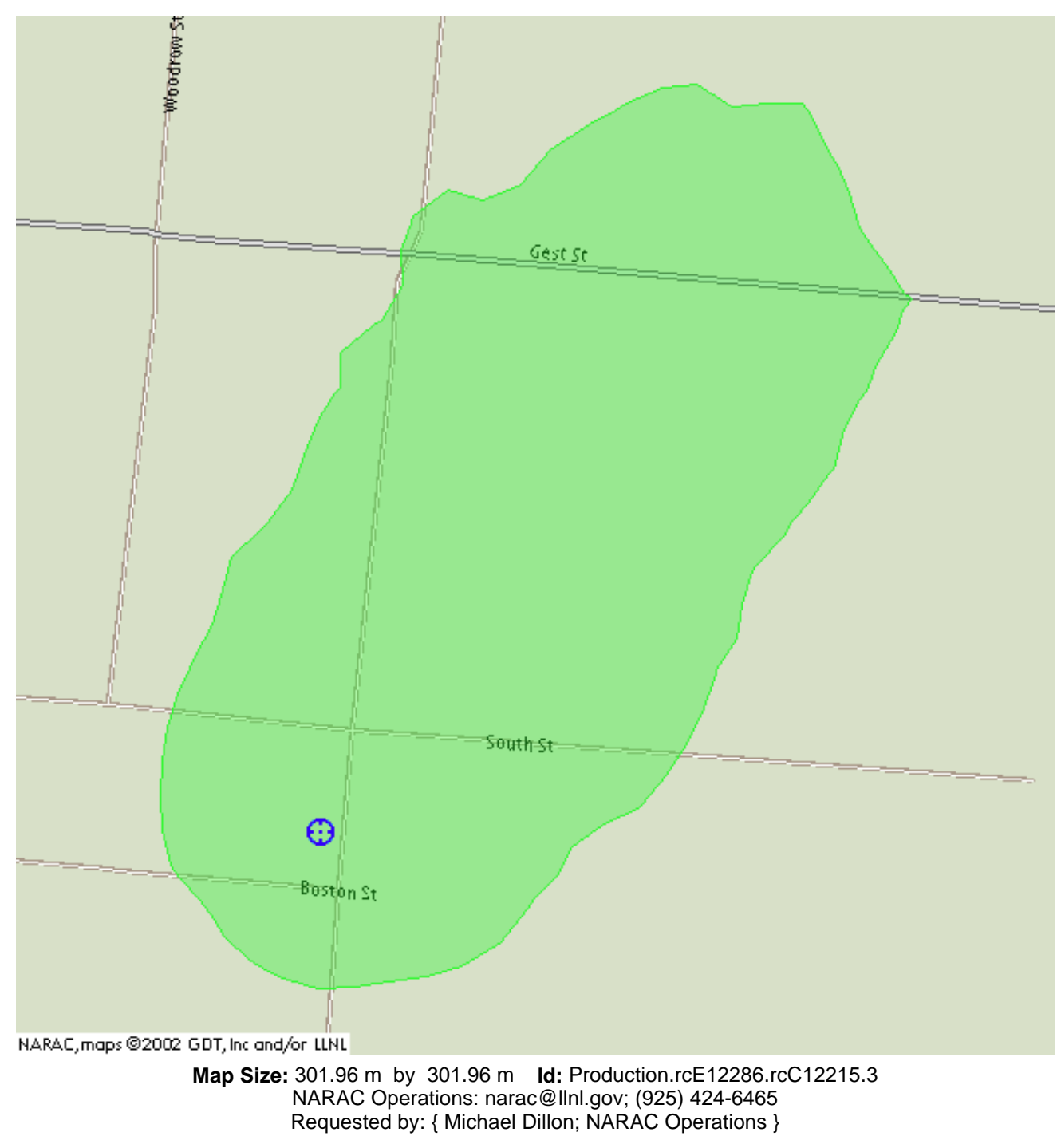

Set 4: Smoldering Plume scaled to measurement

(8.6e6g)

Automated Report - Actual Release

Effects or contamination from 20 Aug 2004 17:00 UTC to 20 Aug 2004 18:00 UTC at or near ground level.

\begin{tabular}{|l|l|l|l|}
\hline \multicolumn{3}{|c|}{ Consequences and Actions } \\
\hline \multicolumn{1}{|l|}{$\begin{array}{l}\text { (ppm) } \\
\text { Area } \\
\text { Extent }\end{array}$} & $\begin{array}{l}\text { Population } \\
\text { Casualties } \\
\text { Fatalities }\end{array}$ & Description \\
\hline$>5.0$ & 27 & \\
$0.03 \mathrm{~km} 2$ & $\mathrm{n} / \mathrm{a}$ & $>10 \%$ of the ERPG -1 \\
$\mathrm{n} / \mathrm{a}$ & $\mathrm{n} / \mathrm{a}$ & \\
\hline \multicolumn{3}{|l|}{ Note: Areas and counts in the table are cumulative. } \\
\hline
\end{tabular}

Source Location: 39.10613N, 84.54837W

Material: BENZENE

Comments: Release starting at

08/20/2004 10:00:00 UTC for $8 \mathrm{hr}$

gridded met at 08/20/2004 04:00:00 UTC

gridded met at 08/20/2004 05:00:00 UTC

gridded met at 08/20/2004 06:00:00 UTC

gridded met at 08/20/2004 07:00:00 UTC

Not For Public Dissemination 